E International

\title{
Implementing Sustainable Urban Travel Policies in Mexico
}

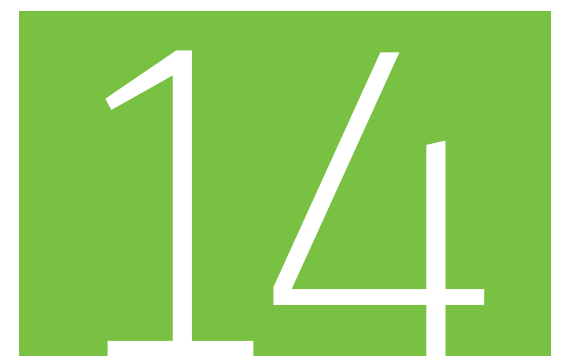

Discussion Paper 2011 • 14

Victor ISLAS RIVERA

Salvador HERNÁNDEZ G. José A. ARROYO OSORNO Martha LELIS ZARAGOZA

J. IGNACIO RUVALCABA

Instituto Mexicano del Transporte 
This document was produced as background for the 2011 International Transport Forum, on 25-27 May in Leipzig, Germany, on Transport for Society. The views expressed in this document do not necessarily reflect those of the member countries of the International Transport Forum.

Further information about the International Transport Forum is available at www.internationaltransportforum.org 


\title{
Implementing Sustainable Urban Travel Policies in Mexico
}

Discussion Paper No. 2011-14

\author{
Víctor Islas Rivera \\ Salvador Hernández G. \\ José A. Arroyo Osorno \\ Martha Lelis Zaragoza \\ J. Ignacio Ruvalcaba \\ Secretaría de Comunicaciones y Transportes \\ Instituto Mexicano del Transporte \\ Sanfandila, Queretaro
}

April 2011 


\section{INTERNATIONAL TRANSPORT FORUM}

The International Transport Forum at the OECD is an intergovernmental organisation with 52 member countries. It acts as a strategic think tank with the objective of helping shape the transport policy agenda on a global level and ensuring that it contributes to economic growth, environmental protection, social inclusion and the preservation of human life and well-being. The International Transport Forum organizes an annual summit of Ministers along with leading representatives from industry, civil society and academia.

The International Transport Forum was created under a Declaration issued by the Council of Ministers of the ECMT (European Conference of Ministers of Transport) at its Ministerial Session in May 2006 under the legal authority of the Protocol of the ECMT, signed in Brussels on 17 October 1953, and legal instruments of the OECD.

The Members of the Forum are: Albania, Armenia, Australia, Austria, Azerbaijan, Belarus, Belgium, Bosnia-Herzegovina, Bulgaria, Canada, Croatia, the Czech Republic, Denmark, Estonia, Finland, France, FYROM, Georgia, Germany, Greece, Hungary, Iceland, India, Ireland, Italy, Japan, Korea, Latvia, Liechtenstein, Lithuania, Luxembourg, Malta, Mexico, Moldova, Montenegro, Netherlands, New Zealand, Norway, Poland, Portugal, Romania, Russia, Serbia, Slovakia, Slovenia, Spain, Sweden, Switzerland, Turkey, Ukraine, the United Kingdom and the United States.

The International Transport Forum's Research Centre gathers statistics and conducts cooperative research programmes addressing all modes of transport. Its findings are widely disseminated and support policymaking in Member countries as well as contributing to the annual summit.

\section{DISCUSSION PAPERS}

The International Transport Forum's Discussion Paper Series makes economic research, commissioned or carried out at its Research Centre, available to researchers and practitioners. The aim is to contribute to the understanding of the transport sector and to provide inputs to transport policy design. The Discussion Papers are not edited by the International Transport Forum and they reflect the author's opinions alone.

The Discussion Papers can be downloaded from: www.internationaltransportforum.org/itrc/DiscussionPapers/itrcpapers.html

The International Transport Forum's website is at: www.internationaltransportforum.org or further information on the Discussion Papers and other JTRC activities, please email:

itf.contact@oecd.org 


\section{TABLE OF CONTENTS}

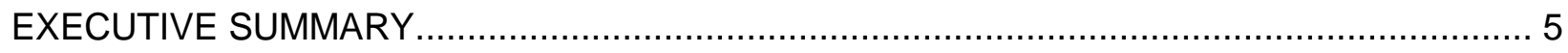

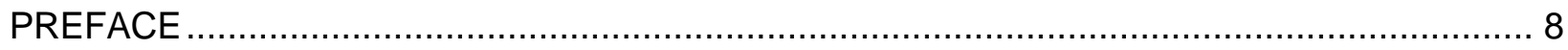

1. URBANIZATION AND MOTORIZATION IN MEXICO ................................................. 9

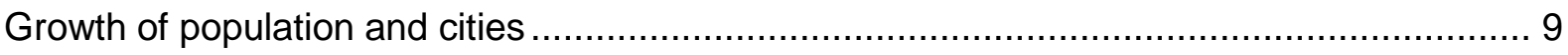

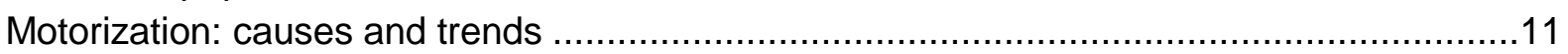

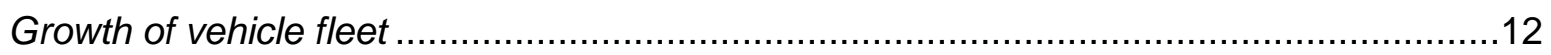

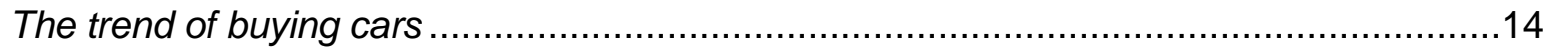

Consumption and the price of gasoline and diesel.....................................................14

2. URBAN TRAVEL TRENDS IN MEXICO CITY ............................................................17

3. TRANSPORT AND AIR POLLUTION IN MEXICO CITY ............................................22

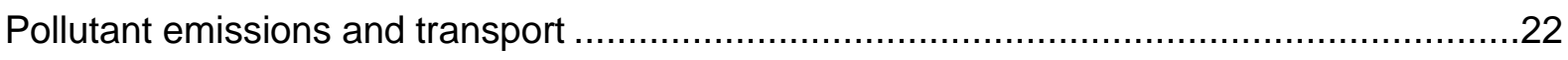

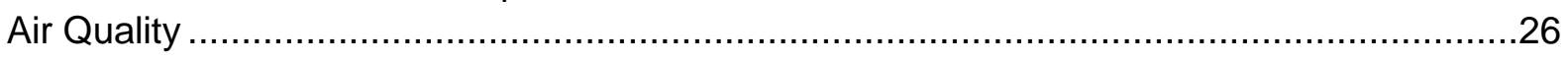

4. INSTITUTIONAL FRAMEWORK AND DECISION MAKING FOR

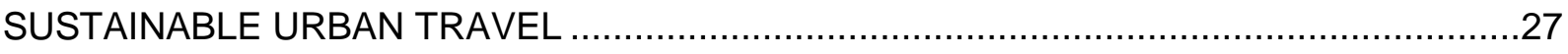

5. TOWARDS A NEW STRATEGY FOR SUSTAINABLE URBAN MOBILITY........................31

Current national strategy for sustainable transportation. ...................................................

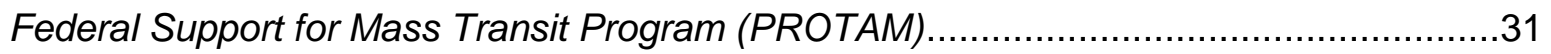

Urban Transport Transformation Project (PTTU) ....................................................... 32

Environmental and Social Management Framework for Urban Transport (MASTU)..........33

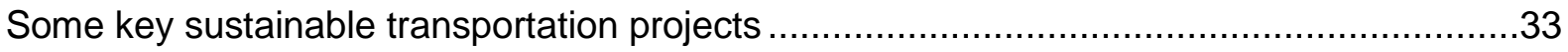

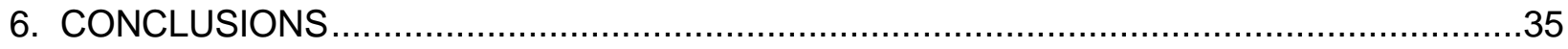

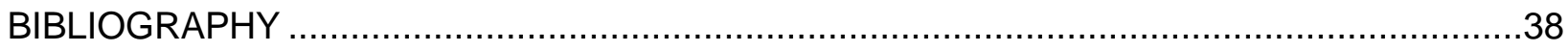

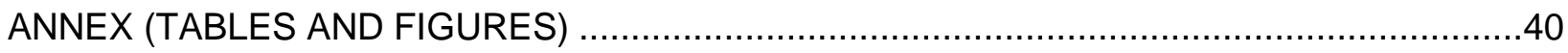




\section{EXECUTIVE SUMMARY}

This report describes the main challenges to urban travel in Mexico. We focus on some of the basic causes of urban transport problems, and we analyze some urban travel policies that could be considered good practices towards sustainable urban development. Mexico City is the emblematic case.

For several decades, urban growth in Mexico has been explosive in terms of urban land use and population, and the number of cars on urban roads has grown even faster. In the last ten years, while the urban population increased from 72.8 million to 86.3 million, the number of motor vehicles increased from 15.6 million to 33.4 million. More than half of the increase in vehicles is probably attributable to cars more than 10 years old imported from the United States, less expensive cars with lesser mechanical, environmental and energy performance. The rate of new car purchase was negative.

Overall demand for gasoline is rising, which is congruent with the increased total quantity of vehicles. Increasing gasoline prices have had little effect on the growth of the car fleet, and when measured at constant prices, the increase is not very high. However, the price of diesel fuel used by urban transport operators increased more rapidly than gasoline, even at constant prices, a situation which does not to favour a shift towards public transport.

Mobility needs in Mexico City grew to 22 million trips daily in 2007. As in most Mexican cities, public transport predominates. Four trips were made in public transit for each trip made in a private car. Unfortunately, public transport's lead is eroding. The bicycle had only a small portion of total trips (1.5\%), and all non-polluting modes (bike, STC subway, trolleybus and light rail transit) had only $17 \%$ of the total.

In 2007, the predominant urban transport user was an adult worker or employee, followed by younger students. An important characteristic of urban mobility is the high number of hours spent on transport. In 2007 the people of Mexico City used about 17.5 million hours daily to travel to their activities. This is equivalent of more than 2.2 million workers doing nothing for eight hours. This comparison with working hours gives us a preliminary idea of the economic and social cost of urban transit that replaces productive activities, rest, family life or education.

Another dimension of transportation in Mexico City is the emission of polluting gases. The analysis in this report found that although these emissions were very large in 2004 (1.8 million tonnes of carbon monoxide, 822 tonnes of organic pollutants, 180000 tonnes of nitrogen oxides, 27000 tonnes of suspended particles, and 6622 tonnes of sulphur dioxide), they are dropping, most significantly in the case of carbon monoxide. This reduction is even more relevant because the pollutant level is already below the level that Mexico considers the maximum permissible. This reduction is occurring as a consequence of various government programs, including the replacement of old vehicles, better fuels, mandatory use of catalytic converters and vehicle inspection programs. 
Perhaps the main obstacle faced by urban transport projects is the lack of modernization of the institutional framework. To some extent, this problem is caused by the relative disdain of certain authorities towards the proposals of transport operators or public transport users. However, we need to emphasize that any transport project must seek the active participation of both authorities and operators/users as an indispensable condition.

In Mexico there are three levels of government: federal, state and municipal.

In most major cities in Mexico, the state government is directly responsible for the planning, design, operation and control of transportation systems, while federal authorities have had a relatively limited participation in projects of urban transport modernization. Municipal governments are restricted to traffic control activities, public security and maintenance of the local road network. It is important to recognize that the design of new public policies to improve the performance of transport systems is not necessarily addressed by a specific level of government.

The federal government has created two programs under the National Development Plan to improve the performance of urban transport in Mexico. In general, both programs anticipate increased efficiency and quality in urban transportation services as well as the containment of negative impacts on the environment. These two programs are the Federal Support for Mass Transit Program (PROTAM) and the Urban Transport Transformation Program (PTTU). The first urges modernization projects for urban and suburban public transport, mainly for cities over 500000 inhabitants. Selected projects must be oriented to providing more efficient, safe, comfortable, reliable and accessible service to the majority of the population. The second is to put urban transport on a growth path of lower carbon emissions, encouraging the use of clean technologies in urban transport.

This report contains a brief description of some of the most recent urban transport projects and government programs that could be seen as good practices for sustainable transport policy. In that sense, it is important to recognize the broad social acceptance of Bus Rapid Transit projects in the cities of León, Guadalajara and Mexico. In addition, we briefly describe the bikeway program and the replacement of old taxis which are among the most emblematic actions of sustainable mobility policy in Mexico City.

The main conclusions and recommendations of this report are the following.

- Mexican government needs to correct the excessive reliance on low-capacity vehicles.

- The main alternative to automobile is the change to mass transit. However, this change could be an efficient solution only if the transportation system in Mexican cities undergoes a process of professionalization.

- Various projects to abate automobile emissions have been effective, but the sustainability of cities is not solely an issue of containment or mitigation of environmental damage to the atmosphere.

- High levels of energy consumption, the lack of control over the sprawl of most Mexican cities, and the low quality of service in almost all public transport services require the search for new options and corresponding public policies. 
- There is an accumulation of gaps in the organizational, technological, operational and infrastructural characteristics of most urban transport firms or groups of operators in Mexican cities.

- The institutional framework that evolved to necessarily high levels of complexity in the past sometimes fails when facing new challenges from emerging social needs, and misses opportunities to adopt new, more efficient technologies.

- Many cities continue traditional management of public transport restricted to the administration of the concession system, mediation in fare disputes, or modernization of the road infrastructure. It is rare to find proposals for public policies that involve, for example, an intermodal profile for reducing environmental and social costs.

- All policies that may affect the central objectives of the strategy for sustainable urban transport, for instance those postulated in PROTAM and PTTU, should be integrated. Two policies that could be reviewed are those affecting the purchase of private vehicles (financing, importation, technologies incorporated, etc.), and those affecting the relative price of fuel for different transportation modes.

- Only mass transit projects that are fully justified economically (including any firm commitment to ongoing public financial support) should be selected, with conditional approval of financial resources subject to a rigorous process of assessment of technical and economic feasibility and compliance with environmental regulations.

- Urban transport systems in Mexican cities must improve the level of coordination and integration between all modes of transport, with actions beyond political rhetoric. For example, electric vehicles and non-motorized transport should be considered as part of an overall vision. Modernization projects should be approved only if they include consideration of all relevant modes and all types of users.

- As part of a strategy to reverse the increasing use of cars, all levels of governments must design and disseminate a "culture of acceptance" toward mass transit. It is important to promote a more favourable attitude in relation to public transport. The strongest form of support for this campaign will be improvement of the quality of public transport.

- For proper implementation of new urban transport policies, improvement in all the instruments of urban transport management at each government level, is needed, covering concession procedures, fares approval, investment regulations, operating regulations, organizational structures and modernization projects.

- The promotion of research and development in the field of urban transport is important for the creation of management tools for mass transportation systems as well as for the creation or adaptation of technologies for vehicles and facilities. 


\section{PREFACE}

Mexico is a country of North America, bounded by the Pacific Ocean and Gulf of Mexico, bordered on the north by the United States of America and on the south by Guatemala and Belize. The country covers 1.97 million $\mathrm{km}^{2}$ and in 2010 had more than 112 million habitants. Mexico celebrated in 2010 the 200 year anniversary of its war of independence and the 100 year anniversary of the civil war that created the current political system. Mexico is a federal republic integrating 32 states. The seat of government and federal authorities are located in the Federal District, which constitutes the main territory of Mexico City.

In 2010 the Mexican Gross Domestic Product (GDP) per capita was USD 9,168 (at rate exchange of 12.8 pesos per dollar), and the annual inflation rate was a relatively low $3.8 \%$. The main trading partners are the United States and Canada. Its main foreign exchange earnings are from oil production, tourism and remittances from overseas workers.

During last century Mexico has shown impressive growth in total population, mainly concentrated in the cities. Urban growth has coincided with problems, not only the crucial issue of transportation needs but also the corresponding consumption of time, health and lives as well as capital resources for infrastructure, vehicles and increasing amounts of energy.

This report aims to review the conditions and main results of sustainable mobility practices currently implemented in Mexican cities. As recognized by an seminal OECD document, "assuring that the growing numbers of urban and suburban dwellers in all socio-economic strata have access to the services and activities integral to their daily lives, while minimising the negative environmental, equity, economic and health impacts of travel, is the principal goal and challenge facing transport and land-use policy-makers at this time. ${ }^{1}$ In that sense, we try to present an overview of conditions that must be taken into consideration when designing a strategic management process for sustainable mobility in Mexico. Because of the importance and leadership of Mexico City in the Mexican context, the analysis focuses mainly on that city.

Before discussing the specific issue of policies and actions directly related with sustainable transport, it is necessary to describe some important issues at the base of such policies. First, we review the magnitude and implications of the urban growth process supported by the intensive use of land, automobiles and energy. Then, we describe the basic features of mobility within the Mexico City. Later, we discuss recent developments in the situation of air pollution in Mexico City, which is probably the most visible manifestation of the problems that arose in the absence of appropriate urban transport management. With these elements as context, we describe the current institutional framework which has been implementing or could implement policies that lead to a comprehensive strategy for sustainable and efficient urban mobility. This report includes a profile of actions or projects that could be part of such strategy, and it report includes some of the main elements to consider in designing a new urban travel policy in Mexico.

1. ECMT-OCDE. Implementing sustainable urban transport policies. CEMT/CM (2001) 13, p. 3. 


\section{URBANIZATION AND MOTORIZATION IN MEXICO}

In this chapter of the report we focus in the main features of the complex process that caused the current problems of congestion, accidents and pollution in most cities of Mexico.

\section{Growth of population and cities}

Although Mexico's population growth shows a clear tendency to decelerate, the current size of population presents many challenges, especially in cities. While the annual average growth rate between 1970 and 1990 was about $2.6 \%$, that rate was only $1.6 \%$ in the period 1990 to 2010. The total population of Mexico in 2010 was more than 112 million inhabitants (Figure 1). This growth has taken place mainly in the cities. Early in the $20^{\text {th }}$ century, just $28.3 \%$ of the population lived in Mexican cities. Today three of every four Mexicans (more than 86 million) live in cities:

Figure 1. Total and urban population

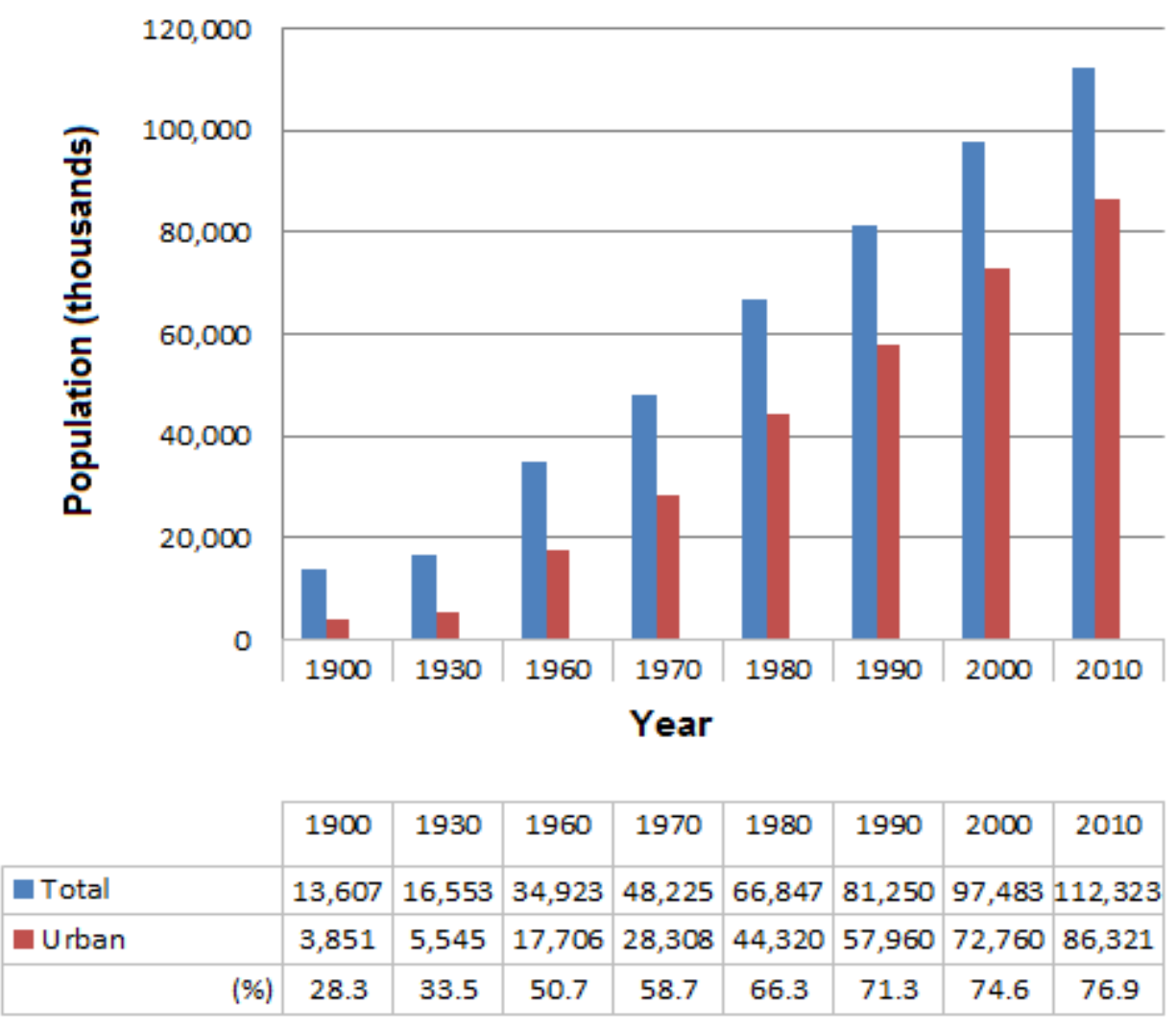

Source: Censos Generales de Población y Vivienda. Resultados definitivos. INEGI, México.

The urbanization process, among other factors, is driven by people migrating to cities looking for a higher standard of living. Thus, as shown in Table 1 (see Annex), the states with the highest levels of urbanization exhibit a trend of higher GDP per capita. The metropolitan area of Mexico City accounts for about $18 \%$ of the total population (Figure 2 ). 
Figure 2. Population in Mexico, and Mexico City

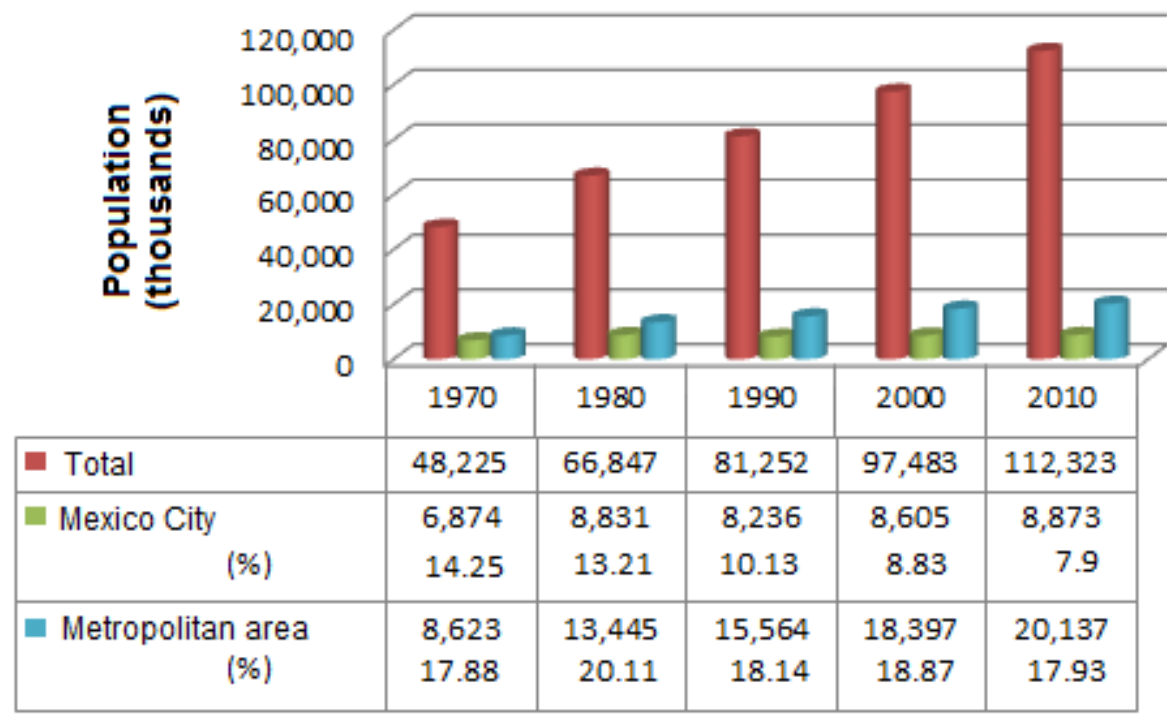

Year

Source: Censos Generales de Población y Vivienda. Resultados definitivos. INEGI, México.

Ten cities in addition to Mexico City have populations exceeding one million (Figure 3). Guadalajara and Monterrey have more than four million inhabitants and represent themselves as megacities.

Mexico City is the main hub of national development. The metropolitan area of Mexico City together with the states of Puebla, Tlaxcala, Mexico, Hidalgo, Morelos and Queretaro form the central region of Mexico (Figure 4), which is a concentration of population, industry and commerce. Therefore, proper management of the transport system is important not only for its own economic and social impact but also because successful public policies in the central region of Mexico can be the basis for the future application of modernization programs in other cities and regions.

In fact, the growth of the central region of the country could be considered a success in the plans for a regional development strategy that considers sustainable mobility. While the Federal District has grown slower than the national average since 1980, the cities and states surrounding Mexico City have grown faster than the national average. 
Figure 3. Population in major cities in Mexico (2010)

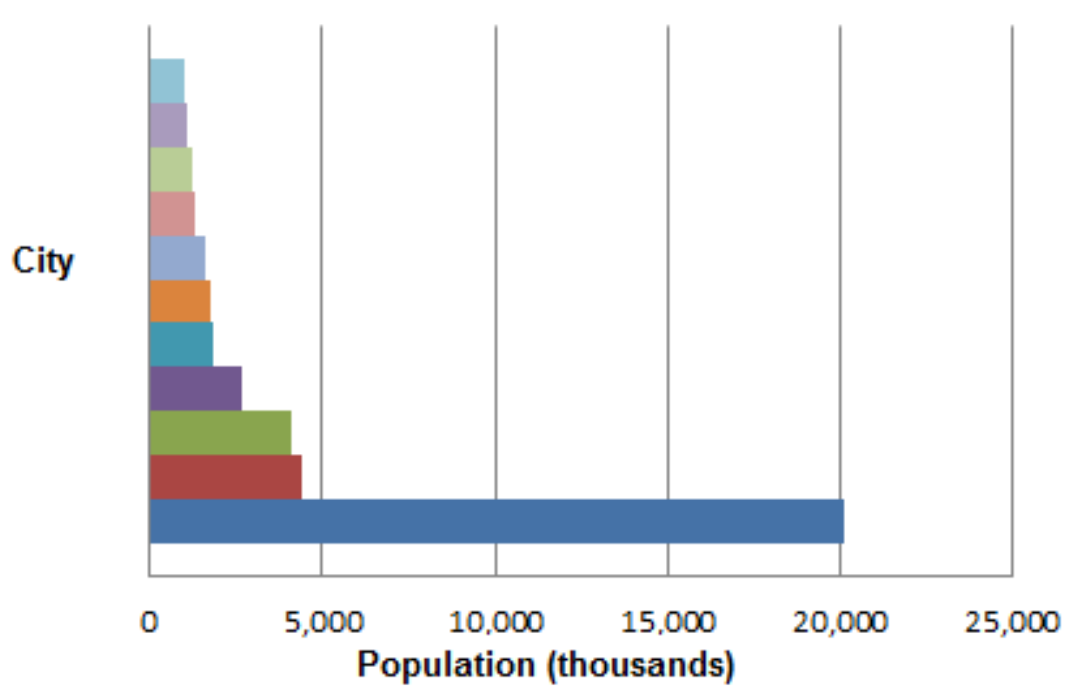

\begin{tabular}{|c|c|}
\hline City & Population \\
\hline San Luis Potosí & 1,041 \\
\hline Que rétaro & 1,097 \\
\hline Torreón- La Laguna & 1,216 \\
\hline Ciudad Juárez & 1,328 \\
\hline León & 1,610 \\
\hline - Tijuana & 1,751 \\
\hline Toluca & 1,847 \\
\hline Puebla- Tlaxcala & 2,668 \\
\hline Monterrey & 4,080 \\
\hline - Guadalajara & 4,434 \\
\hline Mexico City & 20,137 \\
\hline
\end{tabular}

Source: Censo General de Población y Vivienda, 2010. Resultados definitivos, INEGI, México.

An analysis of migration flows and economic performance of the states around Mexico City reveals a process of regional convergence with greater economic interaction between nearby towns and the city of Mexico. This process could be seen as an opportunity for a more balanced urban system, creating opportunities for efficient and sustainable mass transit, such as the Queretaro - Mexico Train. Sustainable options can compete with the increasing use of cars and buses in transport corridors surrounding Mexico City.

\section{Motorization: causes and trends}

As in many countries, politicians have used the figures of increased traffic flow in Mexico as proof of modernity and progress. However, congestion and pollution are changing that view. 


\section{Growth of vehicle fleet}

The increasing number of vehicles is the main factor affecting urban life because of their consequences in energy consumption and environmental damage. A simplified view is that the growth is a natural result of development, solving transportation needs of our growing population. The reality could be more complex, given the options we have to manage the problem. Some data could help to understand the situation.

As could be seen in Figure 6 and Table 2 in the Annex, the total number of vehicles in Mexico has doubled in the last ten years. This growth is more concentrated in some regions and cities than others, causing a real motorization crisis in some geographic areas and at specific points of road networks. The growth of the vehicle fleet exceeds by far the population growth. In 2000 we had a total of 160 vehicles per thousand inhabitants, this indicator rose to almost 300 in 2010 (Figure 6).

Figure 4. Mexico, central region and main cities

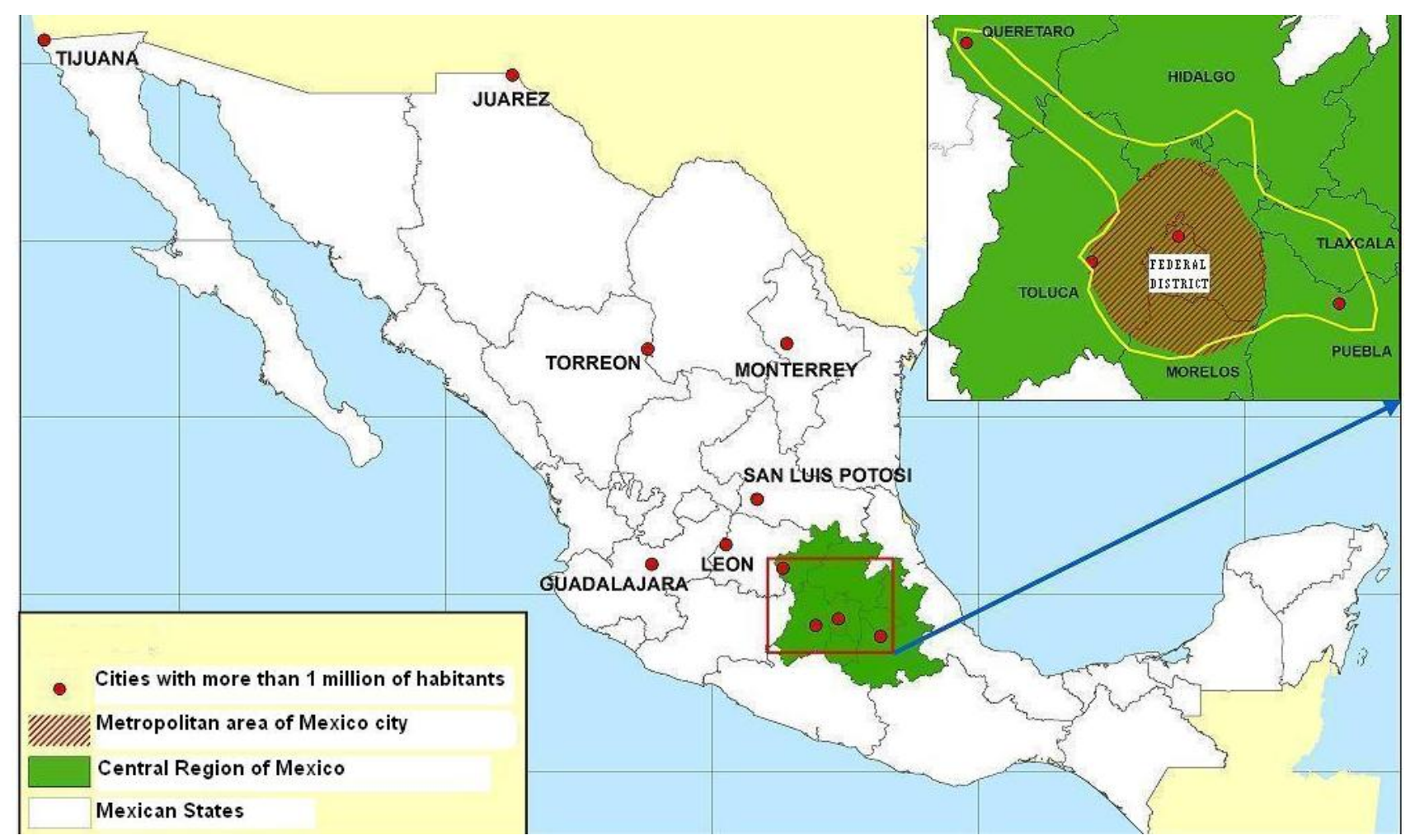

Some states had exceptionally high motorization growth (Table 3 in the Annex), which implies that specific conditions cause rapid regional motorization. Moreover, different measures should be designed for such regional conditions in addition to national policies of general application. For example, Baja California Sur, had the highest rate of motorization, largely due to its low population density, and that low density implies that efficient mass transport projects could face serious financing constraints. 
Implementing Sustainable Urban Travel Policies in Mexico

Figure 5. Population in central region of Mexico

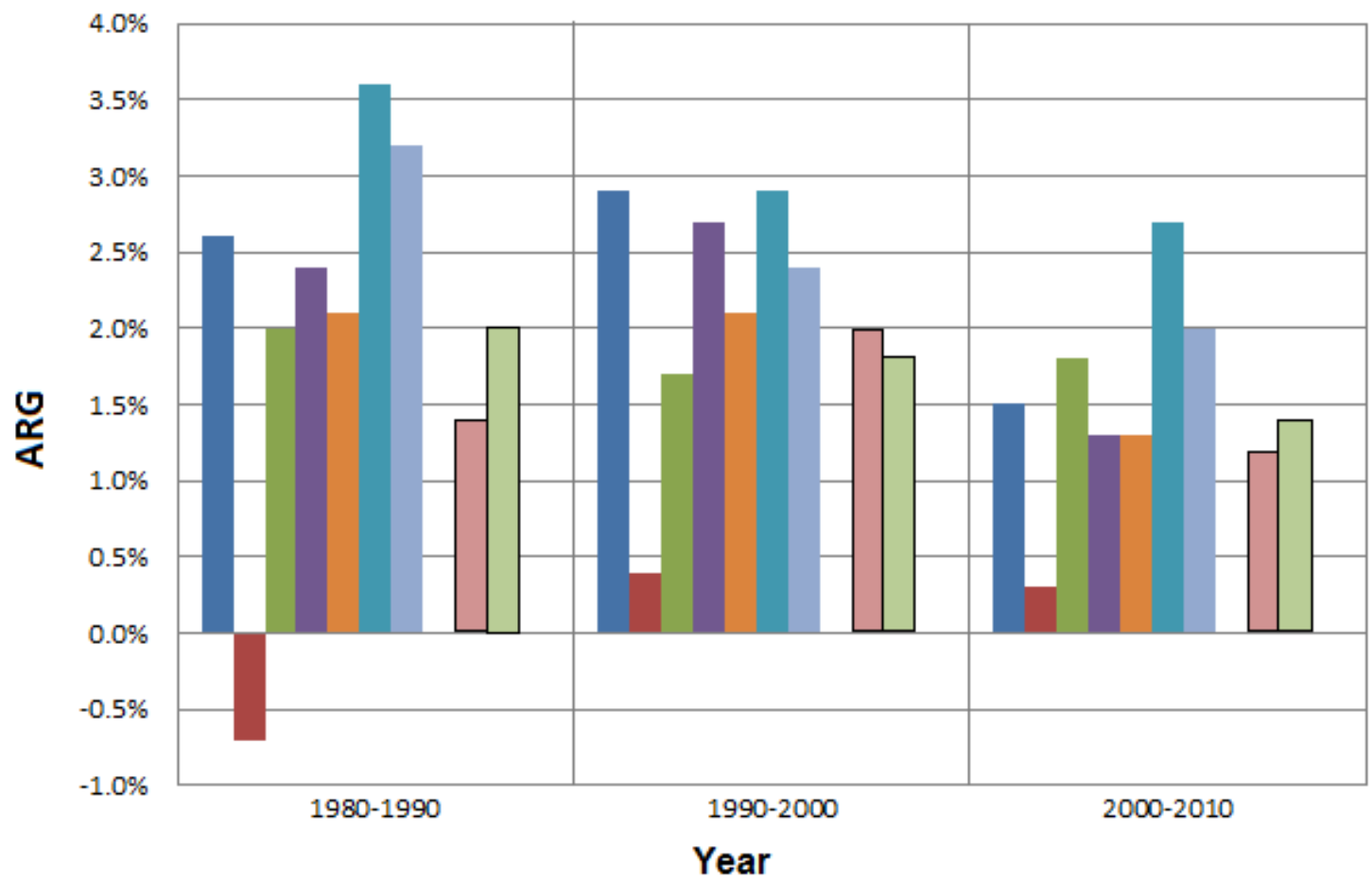

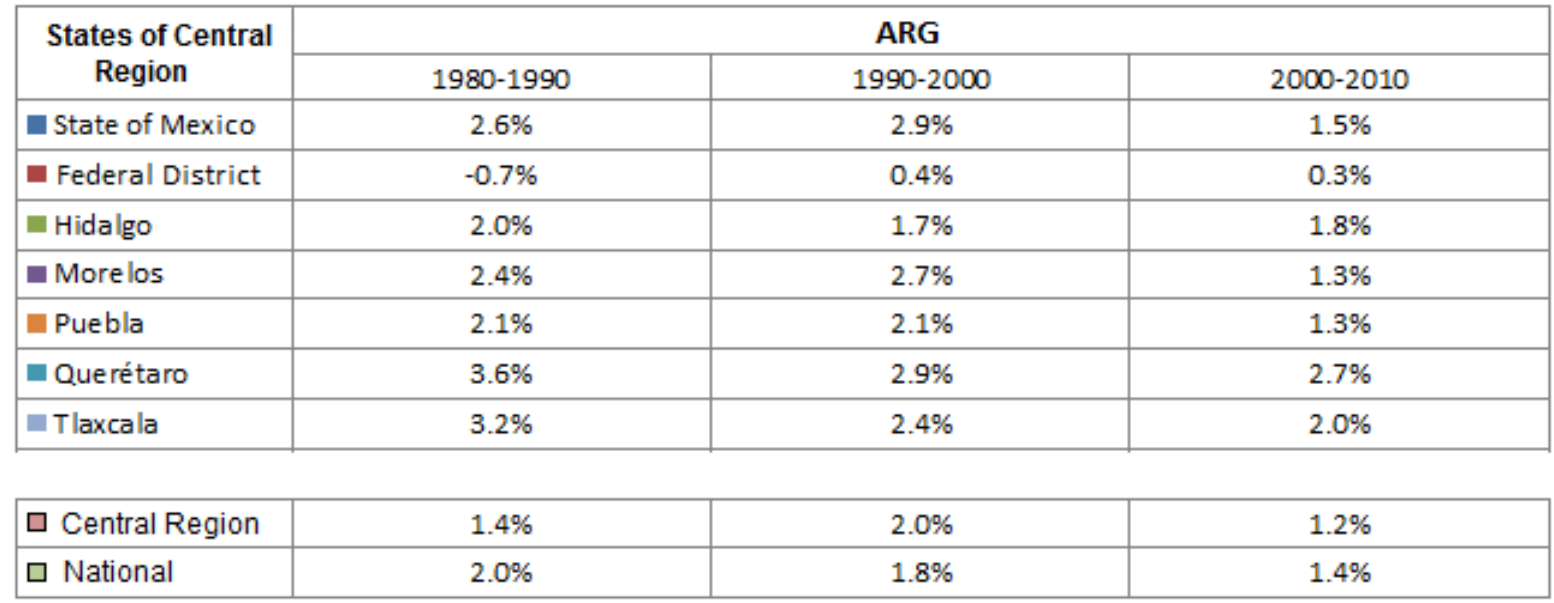

* Note: $A R G=$ average rate of growth.

Source: Censo General de Población y Vivienda 2010. Resultados finales, INEGI, Mexico. 
Figure 6. Motorization Trends in Mexico

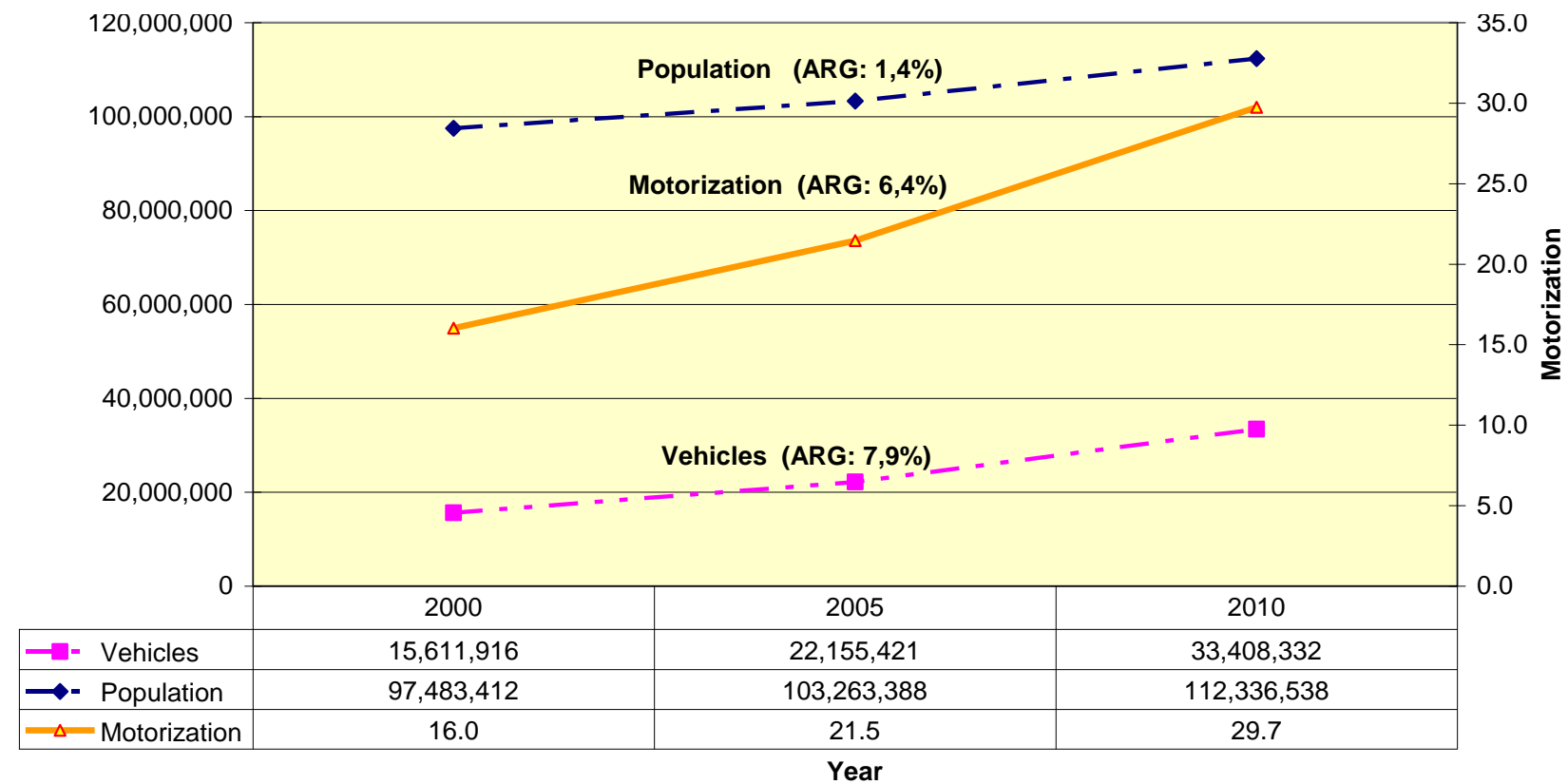

* Note: $A R G=$ average rate of growth.

Source: own calculations based on data from Table 3.

\section{The trend of buying cars}

Over the last ten years inhabitants purchased about eight million new cars (Figure 7). However, there are nearly 17.8 million more vehicles on Mexican roads. This latter figure includes all types of vehicles, and there is a lack of reliable explanatory data. A possible answer lies in the importation of used vehicles mainly from the United States. Because Mexico requires such imports to be more than ten years old, we are concerned that the vehicles could have a poor performance in terms of exhaust emissions and fuel efficiency. This situation could have important energy and environmental implications and must be taken into consideration in a strategy for sustainable transportation.

\section{Consumption and the price of gasoline and diesel}

Figure 8 shows an upward trend in fuel consumption that is congruent with the total number of vehicles travelling Mexican roads. Consumption of gasoline and diesel has an average rate of growth of $3.8 \%$ and $2.5 \%$ respectively in the period from 2000 to 2010 . This increase has a double meaning. First is the concern for environmental damage due to the increased consumption of fossil fuels. Second is the observation that the increasing cost of purchasing fuel does not seem to have diminished demand. The price of "Magna," the most widely used gasoline for cars in Mexico, increased from MXN 5.05 to MXN 8.76 per litre, in the period of 2000 to 2010, at a growth rate of around 5\% (Figure 9).

It is important to note that this increase is smaller than the corresponding increase in the price of diesel used by public transport. The discrepancy does not favour a shift towards public transport. 
Figure 7. Domestic Car Sales

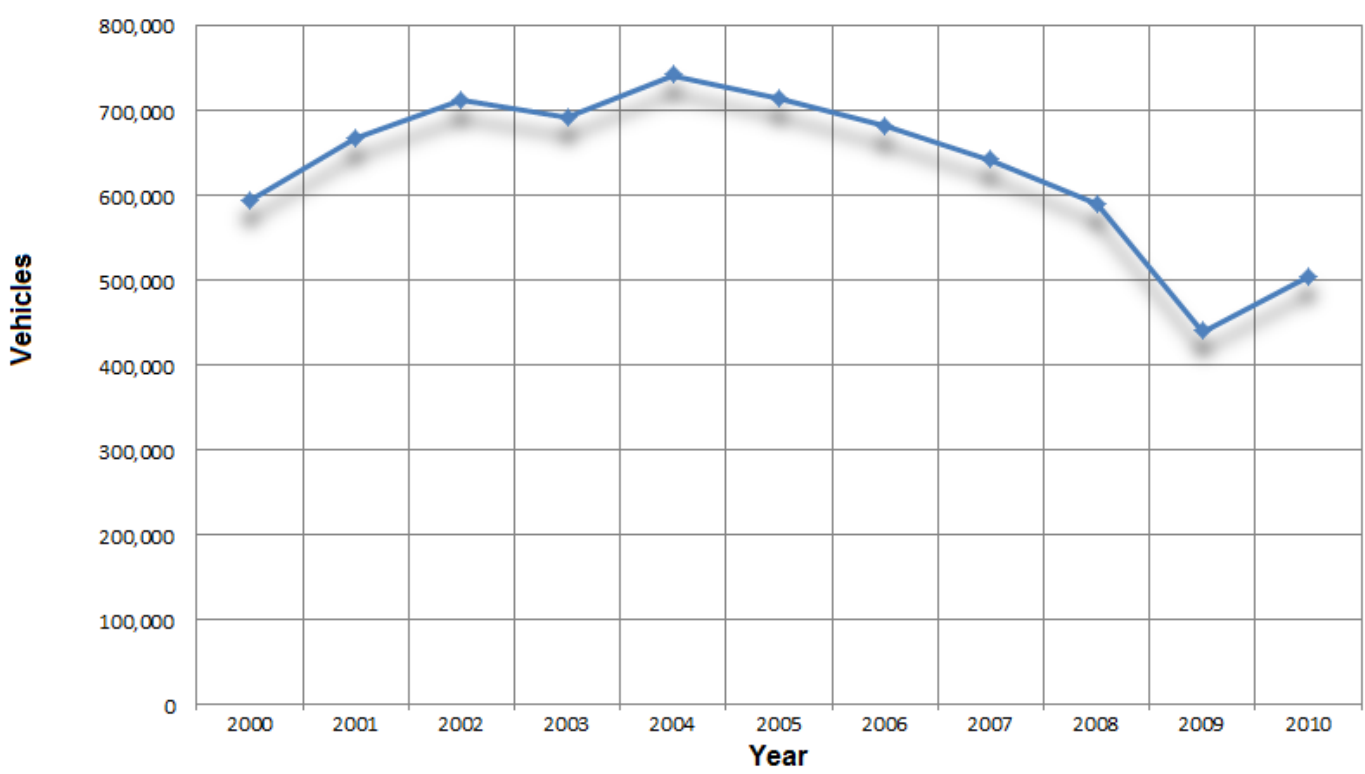

\begin{tabular}{|c|c|c|c|c|c|c|c|c|c|c|c|c|}
\hline & 2000 & 2001 & 2002 & 2003 & 2004 & 2005 & 2006 & 2007 & 2008 & 2009 & 2010 & ARG \\
\hline$\leftarrow$ Car sales & 593,455 & 666,941 & 711,368 & 691,819 & 741,757 & 714,010 & 680,942 & 641,394 & 589,176 & 439,120 & 503,937 & $-1.60 \%$ \\
\hline
\end{tabular}

Source: AMDA, Anuario estadístico, 2010. México.

Considering that the national Consumer Price Index (Figure 10) rose at 3.7\% over the same period, at constant prices the average annual rise in gasoline price is only about $1 \%$.

The increase in the price of diesel explains why the national Producer Price Index of urban transport companies is one of the highest among productive sectors (Figure 10). The obvious consequence of the increase in costs, particularly fuel, is pressure on transport firms to raise fares. If authorities allow such increases, public transport is less attractive to users in terms of relative cost compared to the private car option. However, when local authorities are reluctant to increase fares on public transport for a long time, this situation could lead to delays in maintenance and vehicle replacement, causing a reduction in the quality of transportation service. 
Implementing Sustainable Urban Travel Policies in Mexico

Figure 8. Consumption of gasoline and diesel

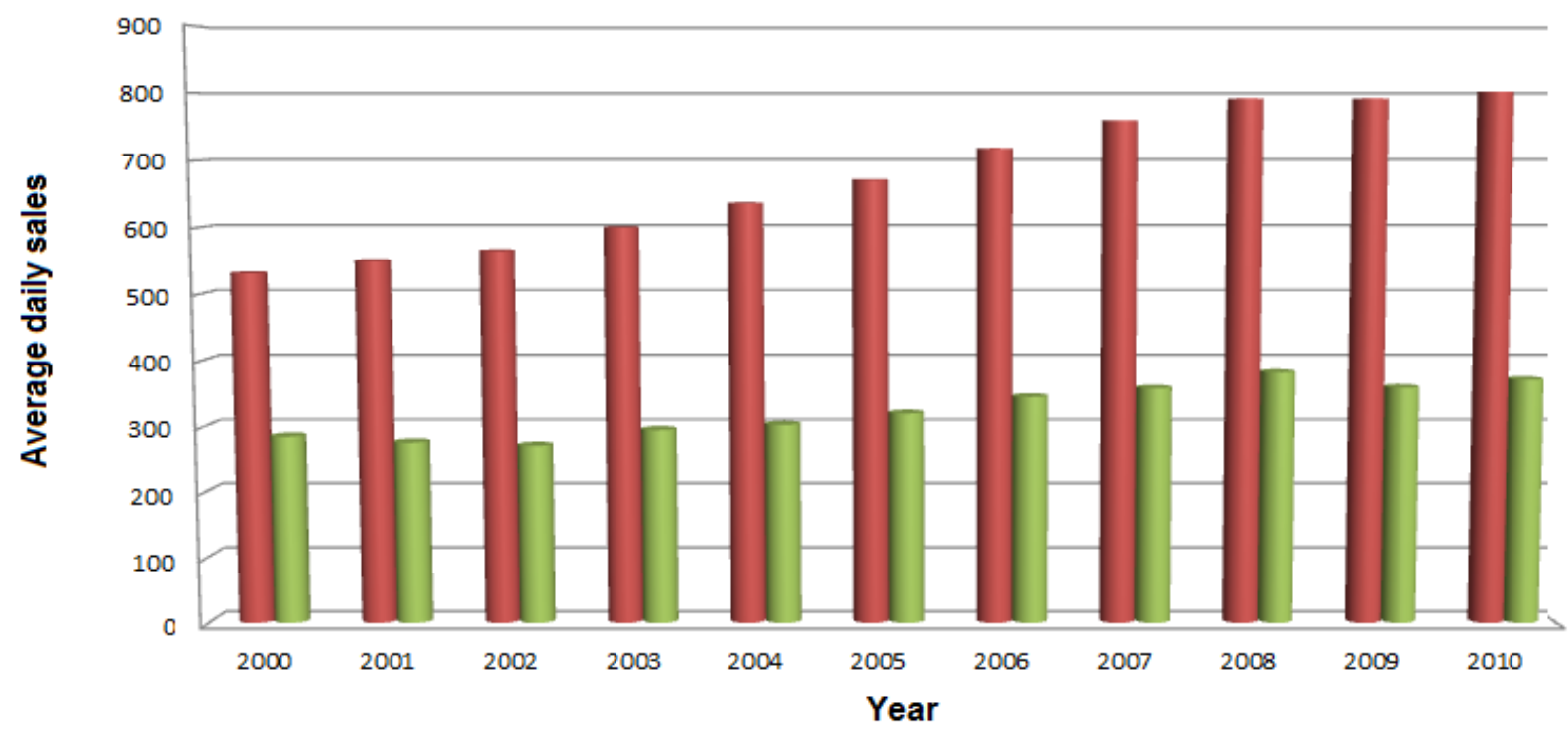

\begin{tabular}{|c|c|c|c|c|c|c|c|c|c|c|c|c|}
\hline & 2000 & 2001 & 2002 & 2003 & 2004 & 2005 & 2006 & 2007 & 2008 & 2009 & 2010 & ARG \\
\hline Gasoline sales ${ }^{1}$ & 531 & 550 & 565 & 600 & 636 & 671 & 718 & 760 & 792 & 792 & 802 & $3.80 \%$ \\
\hline Diesel sales 1 & 285 & 276 & 271 & 295 & 303 & 320 & 345 & 358 & 382 & 359 & 371 & $2.50 \%$ \\
\hline
\end{tabular}

Source: PEMEX, Anuario estadístico, 2010. México.

Figure 9. Gasoline and diesel prices

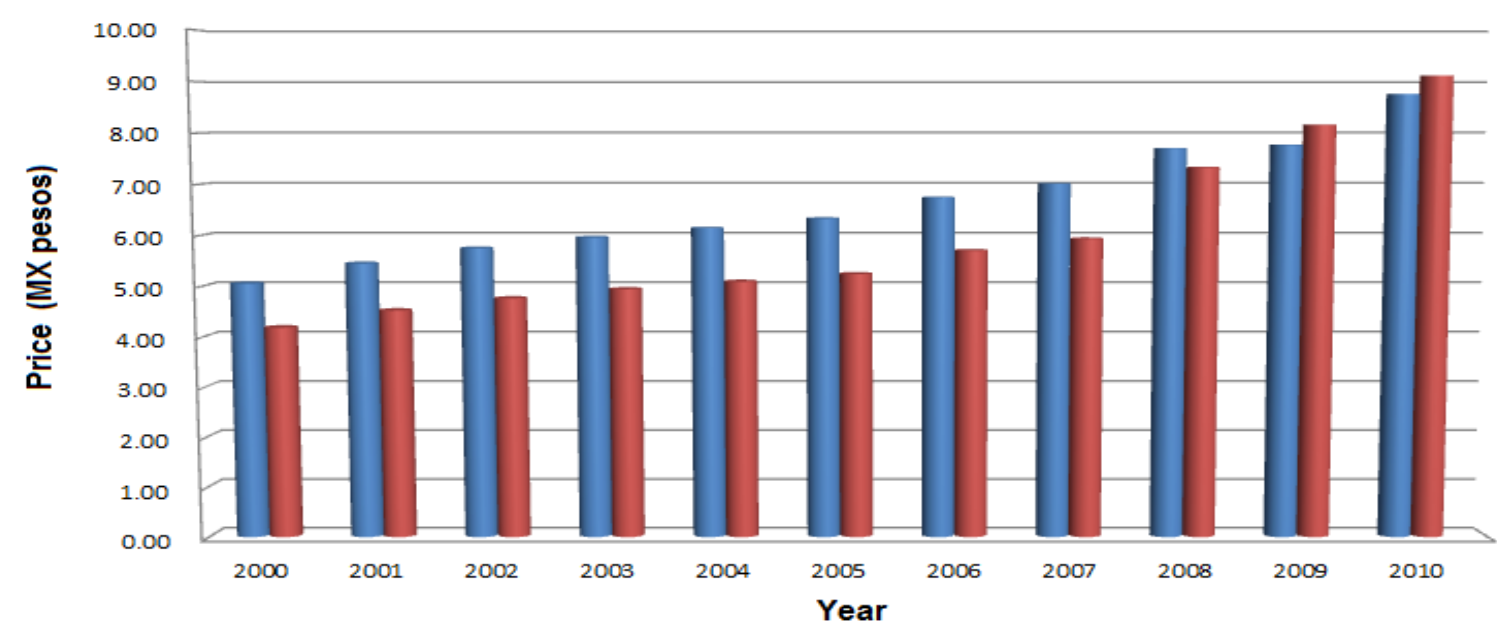

\begin{tabular}{|c|c|c|c|c|c|c|c|c|c|c|c|c|}
\hline & 2000 & 2001 & 2002 & 2003 & 2004 & 2005 & 2006 & 2007 & 2008 & 2009 & 2010 & ARG \\
\hline $\begin{array}{l}\text { Gasoline price } \\
\text { (MX pesos per litre) }\end{array}$ & 5.05 & 5.45 & 5.75 & 5.96 & 6.14 & 6.33 & 6.74 & 7.01 & 7.70 & 7.77 & 8.76 & $4.8 \%$ \\
\hline $\begin{array}{l}\text { Diesel price } \\
\text { (MX pesos per litre) }\end{array}$ & 4.18 & 4.52 & 4.76 & 4.94 & 5.09 & 5.24 & 5.70 & 5.93 & 7.33 & 8.16 & 9.12 & $6.7 \%$ \\
\hline
\end{tabular}

Source: PEMEX, Anuario estadístico, 2010. México. 
Figure 10. Price index

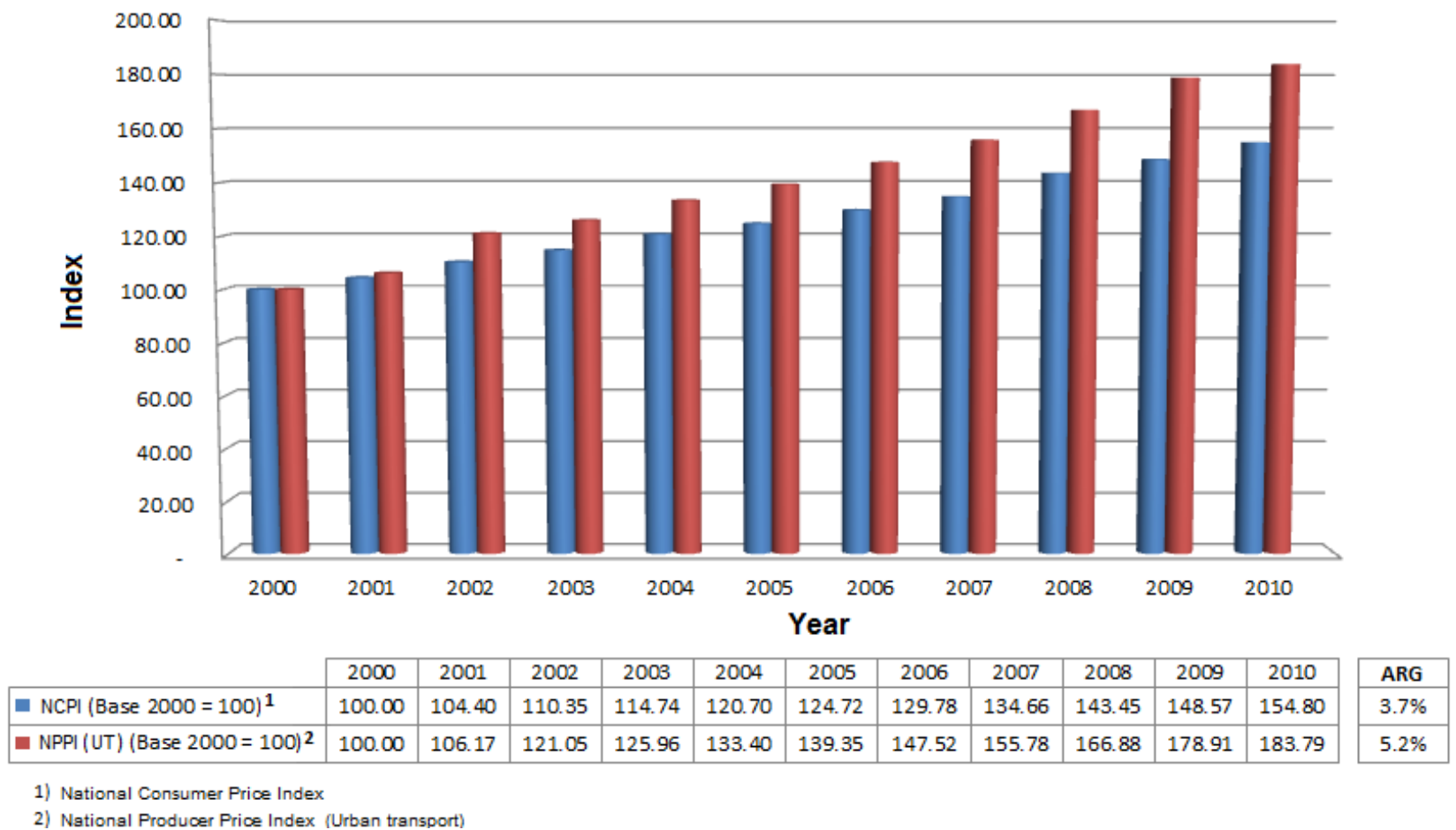

Source: INEGI, 2010. Sistema de cuentas nacionales. México.

\section{URBAN TRAVEL TRENDS IN MEXICO CITY}

The most recent origin and destination survey in Mexico City (EOD, 2007) confirmed the majority of characteristics and mobility trends found in previous studies and included some important changes.

In 2007, the total number of modal trips daily in the Mexico City metropolitan area (MCMA) exceeded 30.4 million (Figure 11). The modal split shows the relative importance of each transport mode, and trends can be seen when comparing the results with those of the 1994 survey (Figure 12). Origin destination surveys distinguish between complete trips from origin to destination and modal trips, the individual portions of a trip using a particular mode of transport. In 2007 there were nearly 22 million complete trips daily, made up of 30.4 million modal trips.

Analysis of data from 1994 and 2007 shows the following characteristics:

- Public transport predominates, with four public transport trips for each trip in private vehicles.

- Car use increased from 4 million trips in 1994 (17.4\% of total) to 6.3 million in 2007 (20.7\% of total).

- Urban buses declined in importance, from $7 \%$ in 1994 to $2 \%$ in 2007, while suburban buses increased from 3.5\% in 1994 to $7 \%$ in 2007. 
- Collective taxis (peseros) remain the most widely used transport option, although their share diminished from 54\% in 1994 to $46 \%$ in 2007.

- Bicycles have a low but increasing share $(0.7 \%$ in $1994,1.5 \%$ in 2007$)$, and the total of non-polluting modes of transport (bicycle, STC-Subway, tramway, trolleybus and light rail) had only $15.2 \%$ of the total in 1994 and $17 \%$ in 2007.

Figure 11. Modal split of trips in the MCMA, during a typical day in 2007

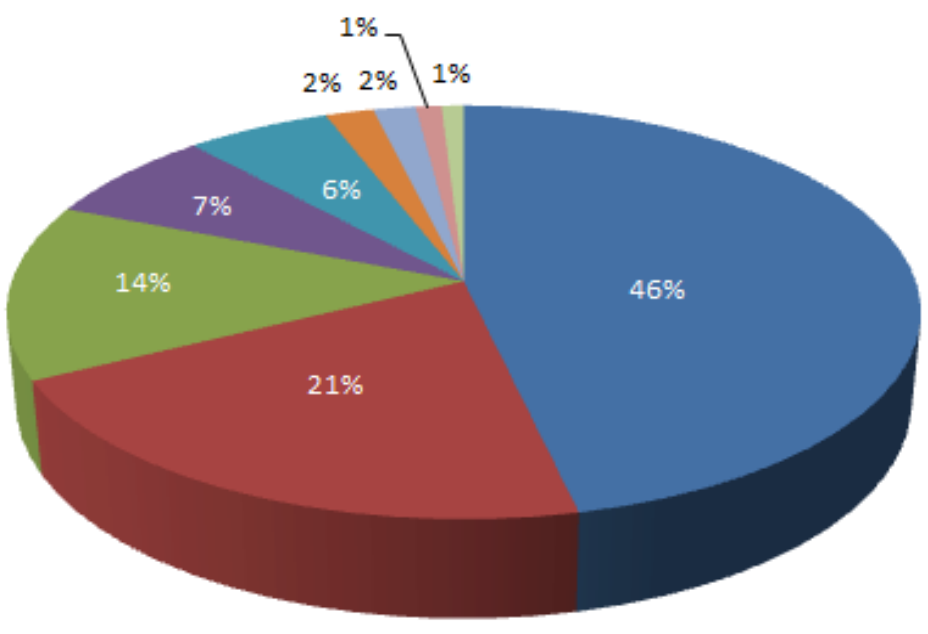

$$
\begin{aligned}
& \text { - Shared taxis } \\
& \text { Cars } \\
& \text { Cistema de Tranșporte } \\
& \text { Colectivo- (Subway) } \\
& \text { - Suburban buses } \\
& \text { - Taxi } \\
& \text { - Urban buses } \\
& \text { Bicycle and motorcycle } \\
& \text { Trolleybus and Lightrain } \\
& \text { - Others }
\end{aligned}
$$

Source: Encuesta 2007, Origen Destino, INEGI, México.

Figure 12. Modal split of trips in the MCMA, during a typical day in 1994

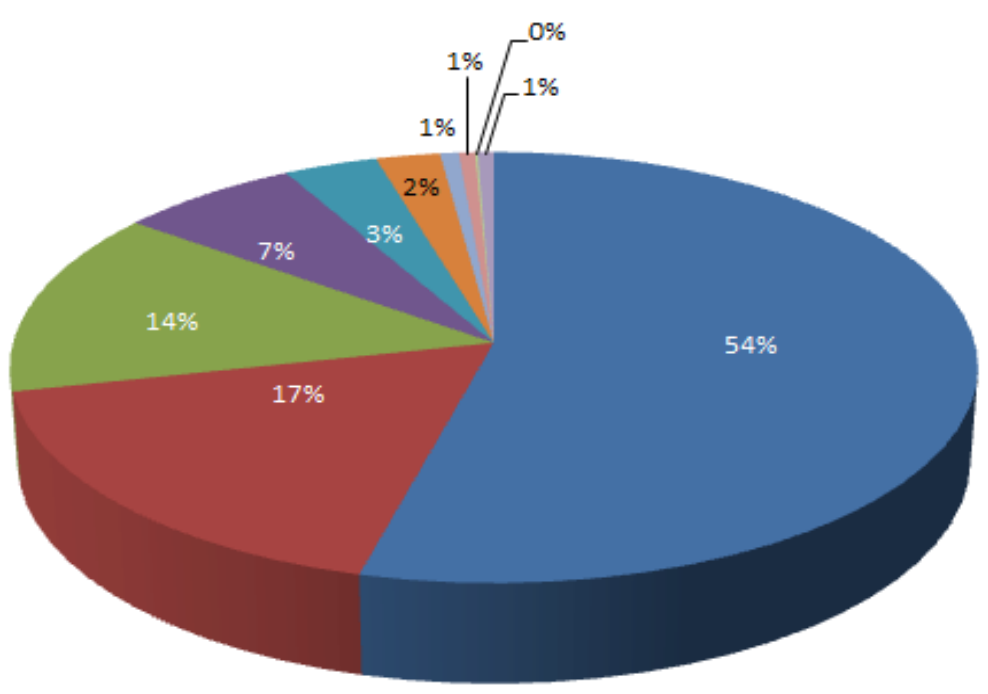

$$
\begin{aligned}
& \text { - Shared taxis } \\
& \text { - Cars } \\
& \text { Sistema de Tranșporte } \\
& \text { Colectivo- (Subway) } \\
& \text { - Urban buses } \\
& \text { - Suburban buses } \\
& \text { - Taxi } \\
& \text { Bicycle } \\
& \text { - Trolleybus } \\
& \text { "wotorcycle }
\end{aligned}
$$

Source: Encuesta de Origen y Destino de los Viajes en el Área Metropolitana de la Ciudad de México, 1994, INEGI. 
Figure 13 compares the age structure of transport users from the origin destination surveys of 1983 and 2007. In 1983, the majority of people traveling within the MCMA were aged 6-24, while the adults (25 to 59 years) were the second largest group. In 2007, the groups are reversed. Those older than 60 are a relatively small but growing fraction. The change is a consequence of changes in the demographic and economic structure of Mexico City and is congruent with the distribution of trip purpose (Figure 14). Trips to school decreased in share, while trips to work increased. The principal purpose of trips is the return home, while trips starting at home have multiple destinations.

Figure 13. Distribution of daily trips by age group in the MCMA.

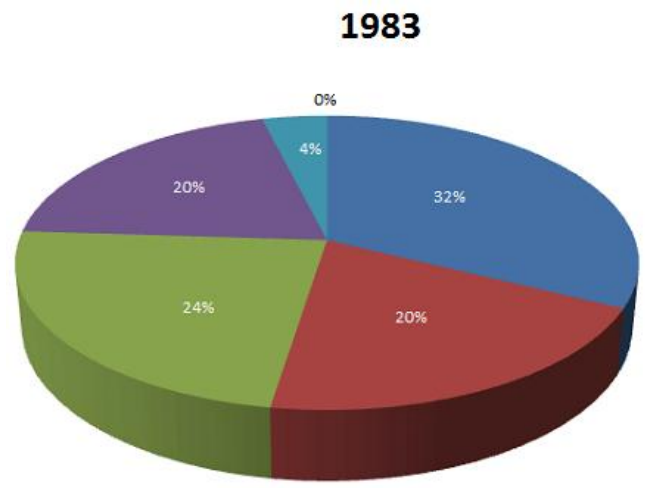

2007

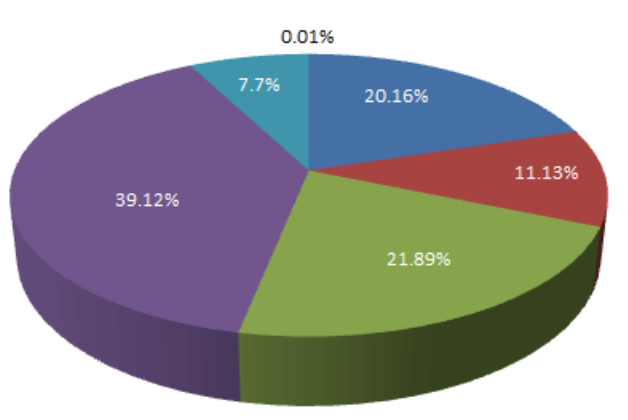

Age group

$=6-19$

$=20-24$

$=25-34$

=35-59

= More than 60

m Unspecified

Age group

=6-19

$=20-24$

= 25-34

= 35-59

- More than 60

- Unspecified 
Figure 14. Distribution of daily trips by purpose in the MCMA

1983

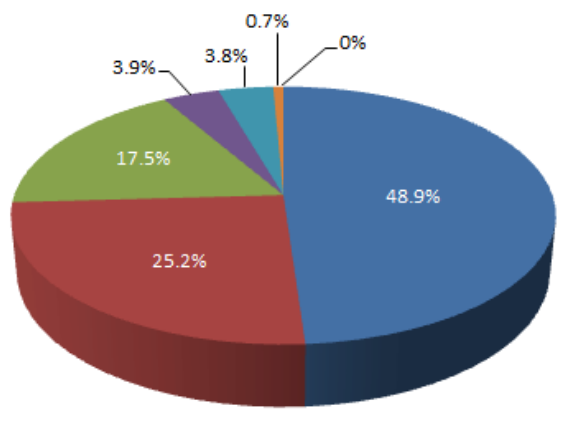

2007

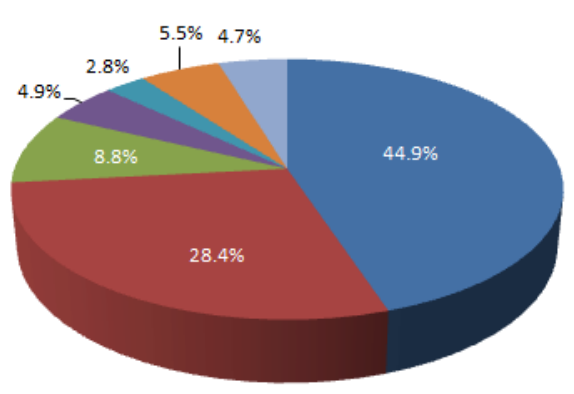

Trip purpose

Back to home

- Work

School

- Buying

Social and

entertainment

Carryng pasengers

Others

Trip purpose

- Back to home

- Work

School

Buying

Social and

entertainment

- Carryng pasengers

others

The total travel time of people going to their economic or social activities (Figures 15 and 16 ) is a most important issue in the design of public policies for transportation in the MCMA. Long travel times can be attributed to three interrelated factors: the expansion of urban sprawl, inefficient public transport and road congestion. A detailed study of the specific importance of each of these factors could lead to more informed design of urban transport policy.

The average travel time is 49 minutes for trips originating in the Federal District and nearly 47 minutes for the suburban zones of Mexico City within the state of Mexico. Trips of less than 30 minutes have increased in importance throughout the MCMA, and trips originating in suburban zones have reduced their average travel time. This could reflect successful urban development in suburban zones encouraging inhabitants to travel to nearby areas and not toward the city centre. A 1983 study found an average travel time of 100 minutes from the city centre to the most remote areas within the urban sprawl. ${ }^{2}$

However, $5 \%$ of trips require excessive travel time of more than two hours. Inefficient transport often burdens poor people disproportionately, as they depend on public transportation and often have the longest commutes.

Based on the data from origin destination surveys, we produced the calculations in Figure 17. The main conclusion is the considerable time spent in transport. In 2007 people of the MCMA travelled about 17.5 million hours a day. This is the equivalent of more than 2.2 million

2. Comisión de Vialidad y Transporte Urbano, 1984. "Estudio de origen y destino del área metropolitana de la ciudad de México, 1983". Departamento del Distrito Federal. México. 
workers doing nothing for eight hours. This comparison with working hours gives us a preliminary idea of the economic and social cost of urban transit that replaces productive activities, rest, family life or education.

\section{Figure 15. Travelling time in the MCMA (1994)}

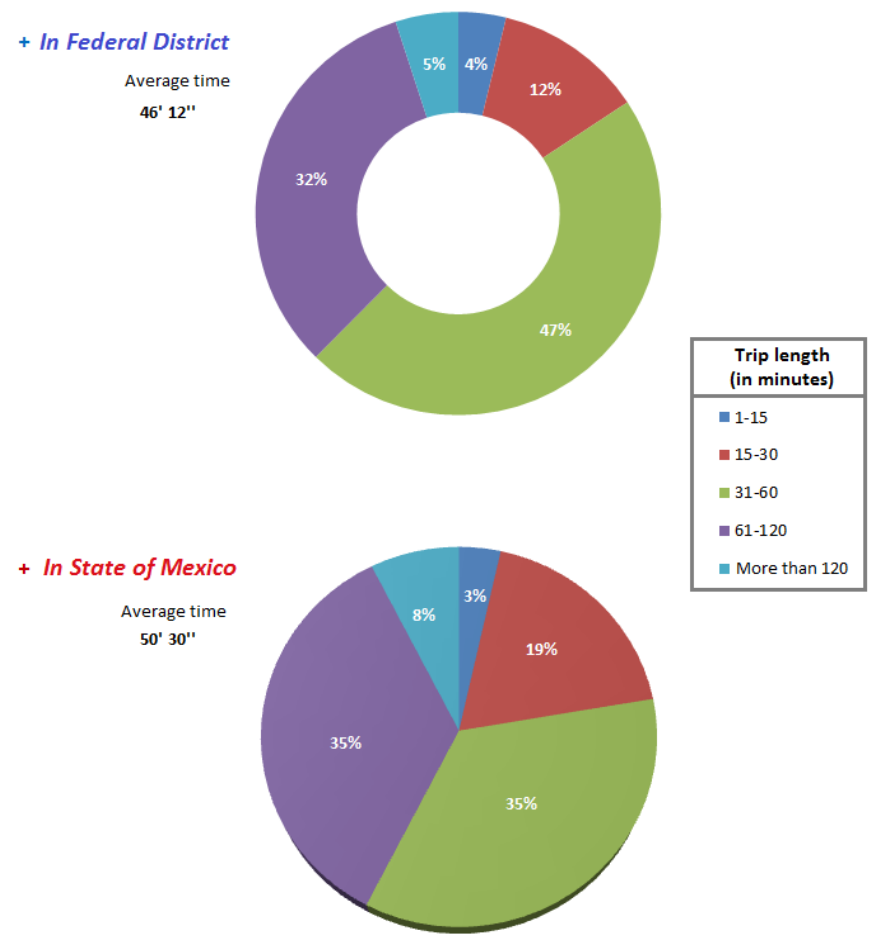

Source: INEGI, 1994. Encuesta de Origen y Destino de los Viajes en el AMCM, México.

Figure 16. Travelling time in the MCMA (2007)

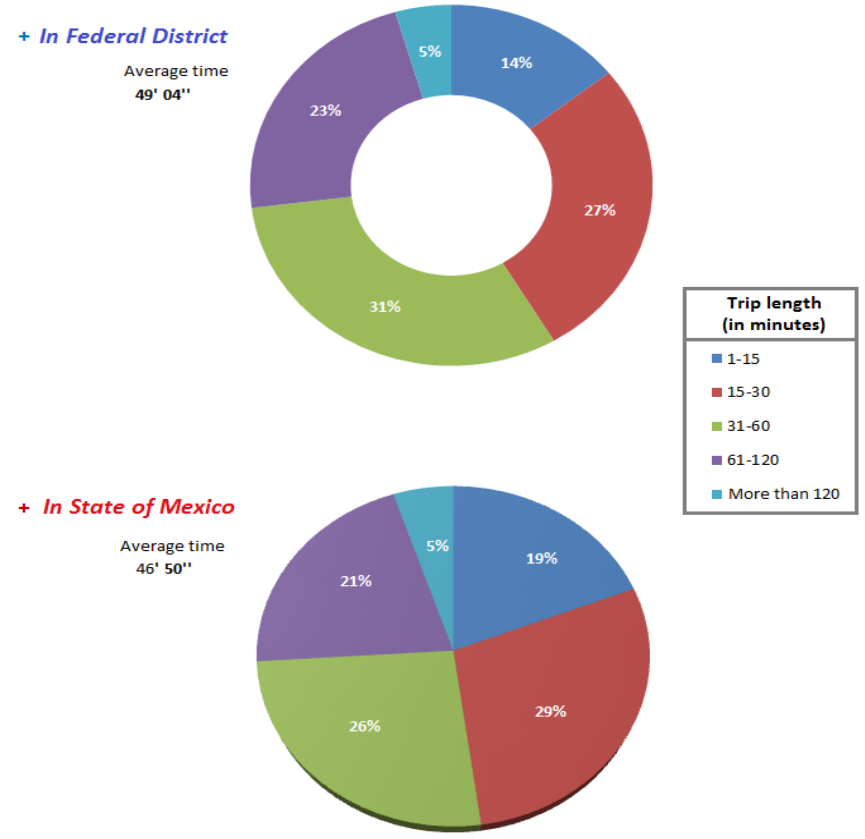

Source: Fuente: INEGI. Encuesta 2007, Origen Destino, México. 
Figure 17. Hours consumed in the daily trips in the MCMA (2007)

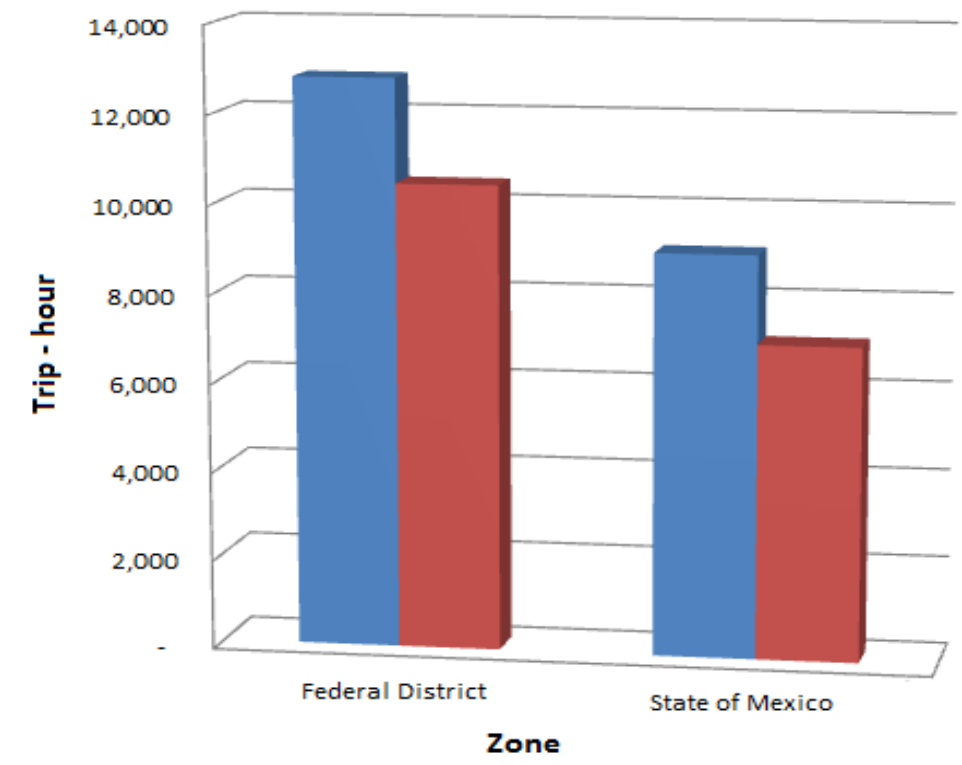

\begin{tabular}{|c|c|c|c|}
\hline & Federal District & State of Mexico & Total \\
\hline Daily trips (thousands) & 12,812 & 9,064 & 21,876 \\
\hline Hours (thousands) & 10,479 & 7,077 & 17,556 \\
\hline $\begin{array}{l}\text { Average trip length } \\
\text { (hours) }\end{array}$ & 0.82 & 0.78 & \\
\hline
\end{tabular}

Source : Fuente: Encuesta 2007, Origen Destino, INEGI.

\section{TRANSPORT AND AIR POLLUTION IN MEXICO CITY}

Transport is a big polluter of the atmosphere, lithosphere and hydrosphere. Atmospheric pollution is the most notorious, and most of the urban population perceive air pollution or suffer its inconveniences. The problem is attributed to traffic congestion and inefficient transport services. This chapter focuses on the analysis of the relationship between the transportation and atmospheric pollution.

\section{Pollutant emissions and transport}

In Mexico City, the most important elements of atmospheric pollution are particles, carbon monoxide, nitrogen oxides, ozone and lead. Other air pollutants are also measured continuously, and the complete list is shown in Table 4 in the Annex.

The "Inventory of Emissions in the MCMA, 2004" (Figure 18), carried out by the Environment Secretariat of the Federal District Government, shows source of the major polluting emissions. The percentage of each source to the total tonnage of pollutants is shown in Table 5 in the Annex. 
Figure 18. Inventory of Emissions in the MCMA, 2004 (table figures in tonnes)

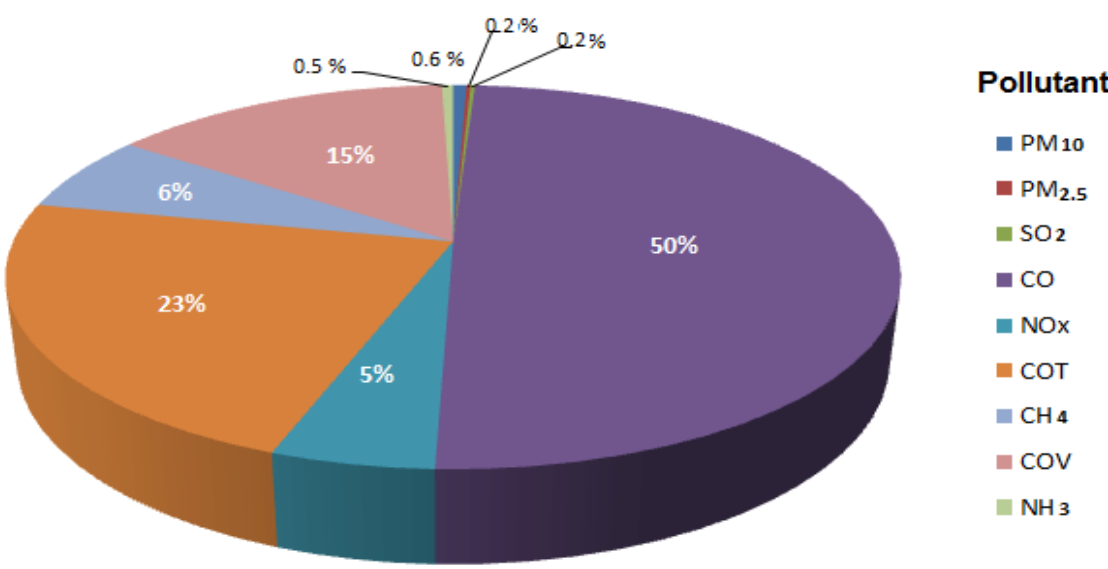

\begin{tabular}{|l|r|r|r|r|r|r|r|r|r|}
\cline { 2 - 10 } \multicolumn{1}{c|}{} & \multicolumn{1}{c|}{$\mathrm{PM}_{10}$} & \multicolumn{1}{c|}{$\mathrm{PM}_{2.5}$} & \multicolumn{1}{c|}{$\mathrm{SO}_{2}$} & \multicolumn{1}{c|}{$\mathrm{CO}$} & \multicolumn{1}{c|}{$\mathrm{NOx}$} & \multicolumn{1}{c|}{$\mathrm{COT}$} & \multicolumn{1}{c|}{$\mathrm{CH}_{4}$} & \multicolumn{1}{c|}{$\mathrm{COV}$} & \multicolumn{1}{c|}{$\mathrm{NH}_{3}$} \\
\hline Local sources & 3,916 & 651 & 3,284 & 6,443 & 19,737 & 119,746 & 1,559 & 114,101 & 196 \\
Area sources & 10,801 & 1,962 & 41 & 7,731 & 11,662 & 487,057 & 223,690 & 216,562 & 13,543 \\
Mobile sources & 4,768 & 3,748 & 3,321 & $1,777,907$ & 147,971 & 198,136 & 9,816 & 183,899 & 3,775 \\
Land and \\
vegetation
\end{tabular}

Source: Own calculations based on data from "Problemática ambiental de la ciudad de México", Sheinbaum, C., 2008, México.

In 2004, the most important atmospheric pollutant in Mexico City was carbon monoxide, measured at 1.8 million tonnes, which was significantly less than the 3.8 million tonnes measured ten years earlier (Figure 19) ${ }^{3}$. More than $99 \%$ of CO emissions came from mobile sources. The second largest atmospheric pollutants were organic compounds (COT), most of which came from such area sources as commercial and domestic use of solvents, as well as from unburned hydrocarbons in the combustion of propane. However, mobile sources were the second largest source of this pollutant. Mobile sources were also the main source of oxides of nitrogen, with $82.2 \%$ of the total of 180000 tonnes. Suspended particles and sulphur dioxide emissions in 2004 declined significantly from 1994.

With this significant reduction of polluting emissions, it is important to know what has been the participation of mobile sources. The private car is the main mobile source of carbon monoxide pollution (Table 6 in the Annex), as well as sulphur dioxide, volatile organic compounds and oxides of nitrogen. Heavy trucks are the largest mobile source of suspended particles.

An obvious question is why a specific mode of transport or type of vehicles generates a given amount of pollutants in a particular year. The precise answer is not obvious. Nonetheless, it is possible to analyze two important aspects. First, the size of the vehicle fleet determines the amount of pollutants it will emit, assuming a specific technological performance, standard fuel efficiency and level of quality in the maintenance and operation. In addition, the volume of emissions depends on the number of vehicle-kilometres.

3. For a more detailed analysis on past emissions, see chapter three of "Llegando tarde al compromiso", Victor Islas, El Colegio de México, 2000. 
Private cars are by far the most popular motor vehicle used for transportation, and their absolute numbers increased the most between 1994 and 2006 (Figures 20 and 21). However, the motorcycle fleet grew at a faster rate and now makes up the second largest mode of motorized transportation. Taxis increased at a high average rate of $6.9 \%$ annually, microbuses did not grow, buses grew by $4.8 \%$ annually, and combis (vans) grew by $3.4 \%$.

Figure 19. Recent trends of annual emissions of pollutants in MCMA

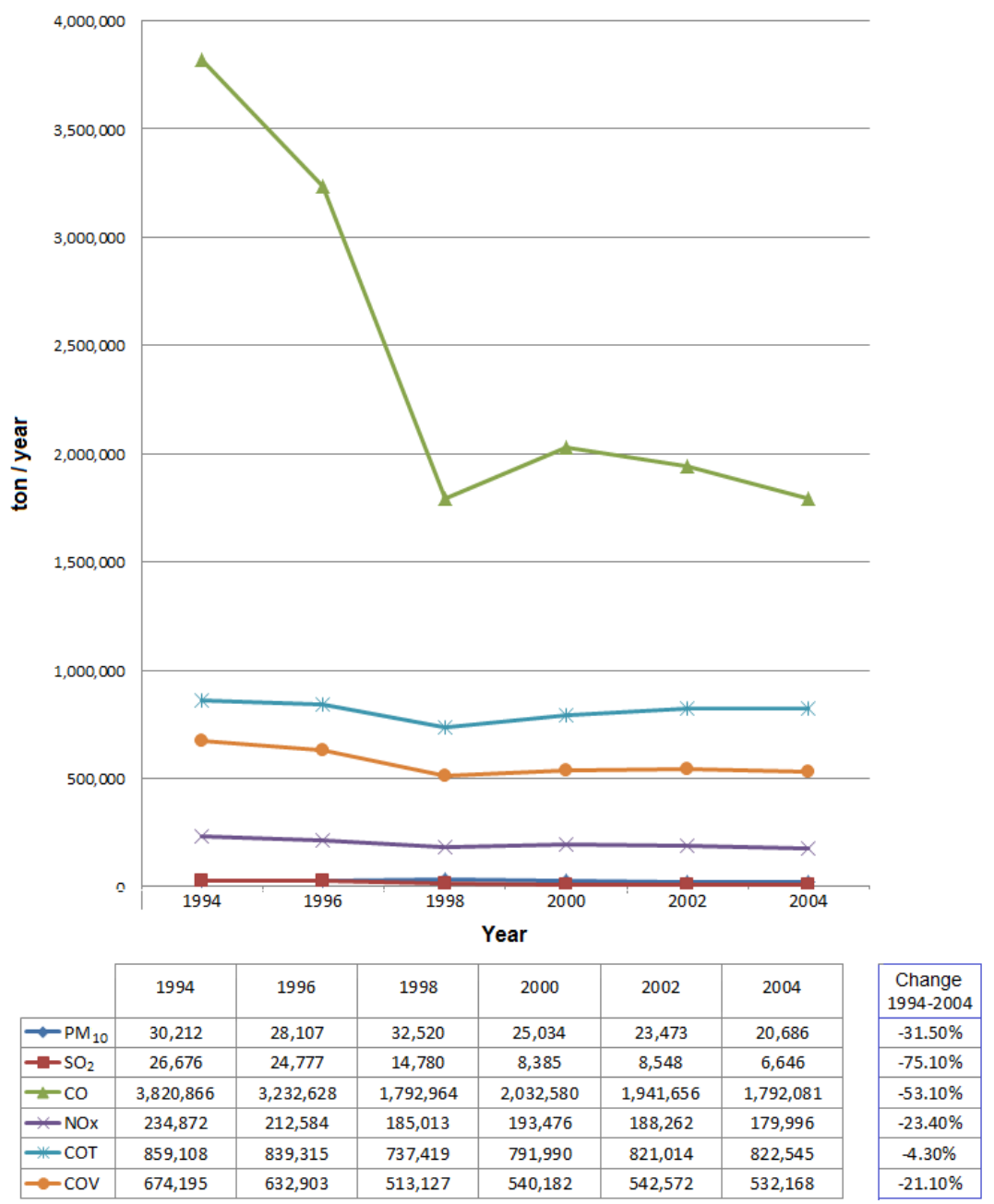

Source: Own calculations based on data from "Problemática ambiental de la ciudad de México", Sheinbaum, C., 2008, México.

The comparison of fleet size with total emissions of mobile sources (Table 6 in the Annex) indicates the relationship between the number of vehicles and the contribution of a transportation mode to specific pollutants. Given the great concern about the high levels of carbon monoxide in Mexico City and the fact that private cars are the largest source of this pollutant, it is essential to strengthen policies that curb their growth.

However, in addition to fleet size, other factors must be considered, such as the number of kilometres driven by certain vehicles in a certain period. Table 7 in the Annex shows the growth of vehicle-kilometres between 1994 and 2006. It is noteworthy that while the number of private cars grew by $66 \%$ between 1994 and 2006, their total travel increased by over $75 \%$. Results are similar for other types of vehicles. Almost all of them are being used more intensively, and consequently they contribute to a volumetric growth of air pollution. 
Figure 20. Passenger car fleet size in MCMA, 1994-2006

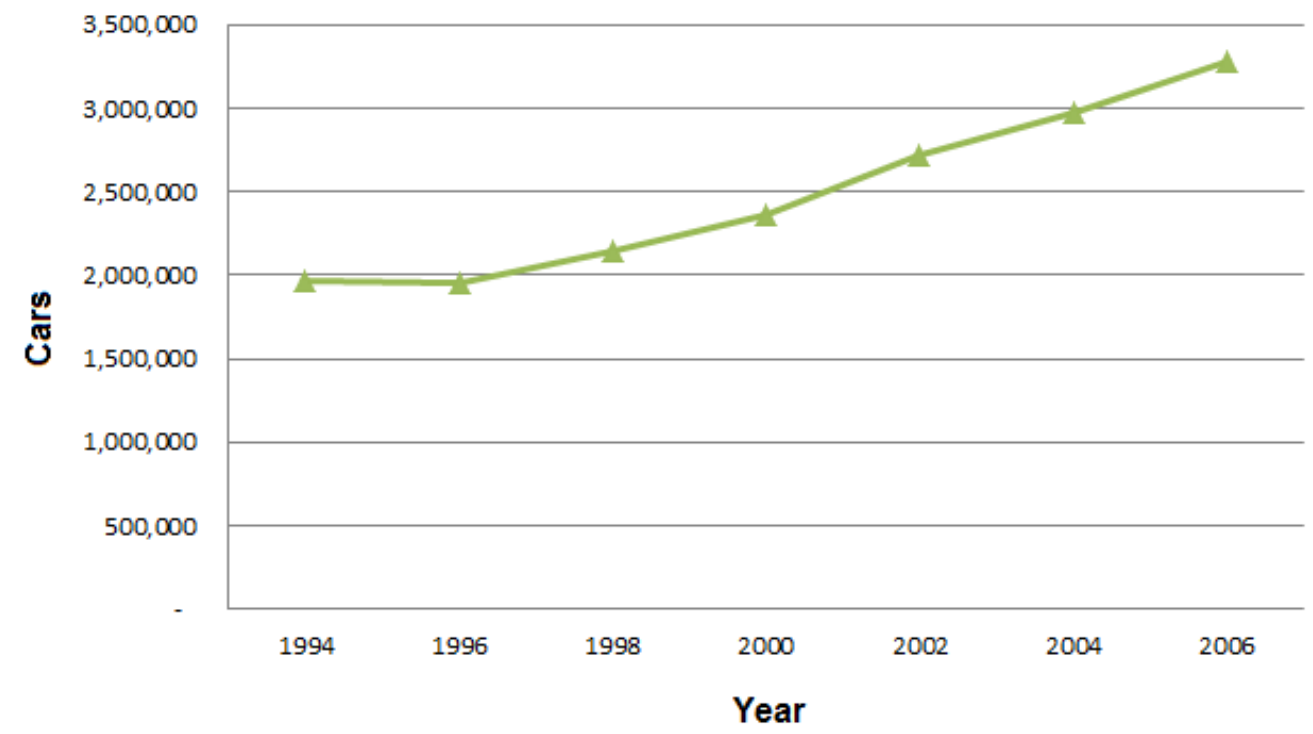

\begin{tabular}{|c|c|c|c|c|c|c|c|c|}
\hline Type of vehicle & 1994 & 1996 & 1998 & 2000 & 2002 & 2004 & 2006 & ARG \\
\hline$-\quad$ Cars & $1,969,277$ & $1,947,464$ & $2,147,448$ & $2,364,031$ & $2,722,080$ & $2,967,893$ & $3,275,567$ & 4.3 \\
\hline
\end{tabular}

Source: Own calculations based on data from "Problemática ambiental de la ciudad de México", Sheinbaum, C., 2008, México.

Technological characteristics, mainly fuel efficiency and mechanical quality, have an important effect on environmental performance of vehicles. Also, in the case of public transport, the level of organization, training and expertise of the transport operator could be very important contributors. Moreover, factors like the physical environment or a congested road network could cause increased pollutant emissions. A detailed analysis of these factors is beyond the scope of this report. However, we can look at the specific case of vehicles operating in the MCMA during 2004, in order to understand their performance in the current context of Mexico City. Table 8 in the Annex shows the average amount of polluting emissions per kilometre for each type of vehicle. For example, Table 8 indicates that average carbon monoxide emissions for a passenger car were about 20 grams per kilometre. Emissions for a specific car depend upon the characteristics of the vehicle and its use. 
Figure 21. Fleet size in MCMA, 1994-2006

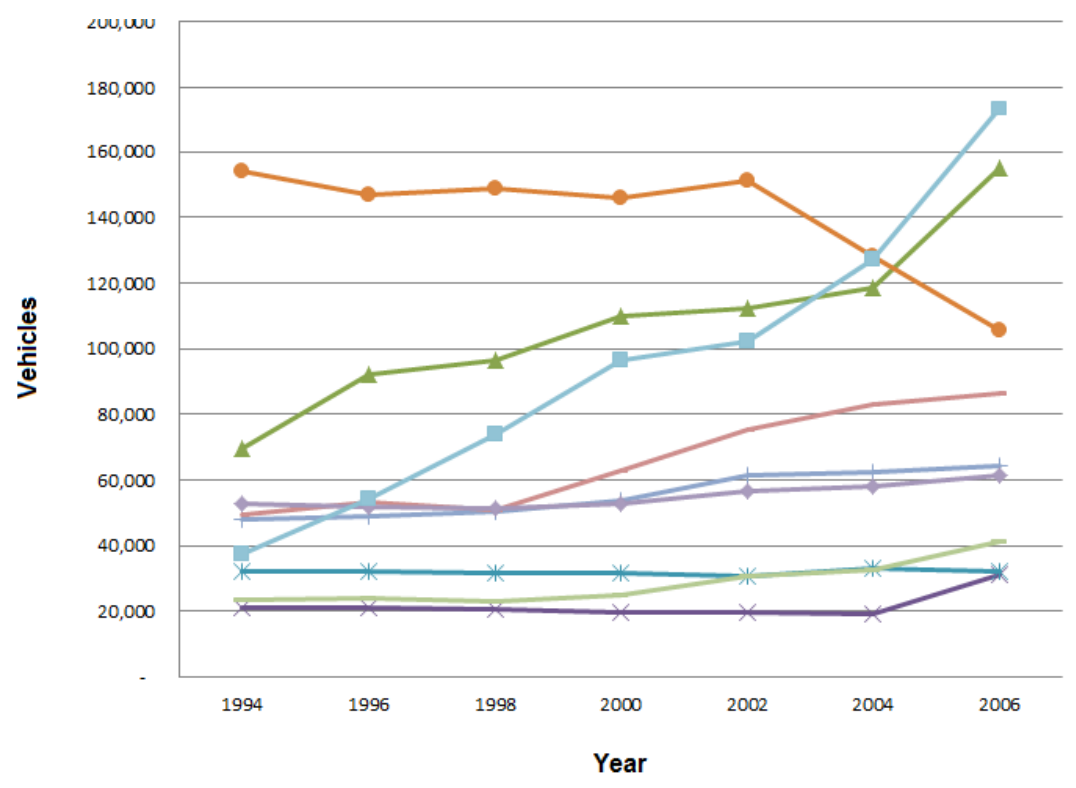

\begin{tabular}{|c|c|c|c|c|c|c|c|c|}
\hline Type of vehicle & 1994 & 1996 & 1998 & 2000 & 2002 & 2004 & 2006 & ARG \\
\hline- Taxis & 69,745 & 92,222 & 96,639 & 109,792 & 112,452 & 118,634 & 155,126 & 6.9 \\
\hline$\leftarrow$ Combis & 20,963 & 20,963 & 20,820 & 19,825 & 19,700 & 19,485 & 31,418 & 3.4 \\
\hline *Microbuses & 32,346 & 32,346 & 31,590 & 31,949 & 30,757 & 33,051 & 32,419 & 0 \\
\hline$\leadsto$ Pick Up & 153,916 & 146,748 & 148,896 & 145,846 & 151,218 & 128,281 & 105,761 & -3.1 \\
\hline Up to 3 tons vehicles & 48,172 & 49,189 & 50,572 & 53,607 & 61,494 & 62,543 & 64,613 & 2.5 \\
\hline Heavy trucks & 49,667 & 53,333 & 51,017 & 62,886 & 75,575 & 83,034 & 86,324 & 4.7 \\
\hline Buses & 23,561 & 23,829 & 22,884 & 24,896 & 30,656 & 32,565 & 41,198 & 4.8 \\
\hline$\rightarrow$ More than 3 tons vehicles & 52,730 & 51,934 & 51,584 & 52,804 & 56,744 & 57,913 & 61,368 & 1.3 \\
\hline- Motorcycles & 37,667 & 54,408 & 73,869 & 96,703 & 102,499 & 127,454 & 173,372 & 13.6 \\
\hline
\end{tabular}

Source: own calculations based on data from "Problemática ambiental de la ciudad de México", Sheinbaum, C., 2008. México.

Under the criteria of the emissions per kilometre, the passenger car is not the worst polluter. Light and heavy trucks, vans and microbuses all emit more carbon monoxide per kilometre. Because commercial vehicles are used intensively, a more frequent vehicle turnover and a substantial improvement in maintenance and operation practices likely could reduce carbon monoxide emissions in Mexico City.

In the case of volatile organic compounds, cargo vehicles again have the highest pollution per kilometre, followed by minibuses and vans and accompanied by buses. Trucks and buses are the worst performers in emissions for nitrogen oxides, PM10 and PM2.5. Buses are the biggest polluter per kilometre for SO2 emissions.

\section{Air Quality}

Mexico City has a history of air pollution, and for several decades, government has implemented various programs to improve air quality. Among the most important are those relating to transport, roads and urban development.

Mexico City has a reasonably reliable system for monitoring air quality. The Environment Secretariat of Federal District Government produces reports on air quality in Mexico City. Using the most recent edition of 2009, we evaluate the evolution of the main indicators of pollutant concentrations from 1988 to 2009 (Table 9 in the Annex). 
There is a clear downward trend in almost all concentrations of pollutants in Mexico City with the exception of nitrogen oxides. Carbon monoxide emissions have been reduced to less than a quarter of the values observed in 1988. This reduction is even more relevant when considering the concentration levels acceptable for humans (Table 10 in the Annex).

Similarly, in 2009, PM10 levels are reduced to $60 \mu \mathrm{g} / \mathrm{m} 3$ and PM2.5 levels down to 21 $\mu \mathrm{g} / \mathrm{m} 3$, while those for the SO2 and lead are 0.006 and 0.04 parts per million, respectively. All these pollutants are already below the levels that Mexico considers to be the maximum allowable concentration.

This general downward trend is a consequence of various government programs that seem to be achieving their goals. These programs include the replacement of old vehicles, better fuels, mandatory use of catalytic converters and vehicle inspection programs.

\section{INSTITUTIONAL FRAMEWORK AND DECISION MAKING FOR SUSTAINABLE URBAN TRAVEL}

This chapter reviews the institutional framework directly related to transport decision making in Mexican cities. Transport systems require a set of institutions and rules for good functioning. A failed institutional framework helps to create conditions for chaos in transport service and increases the economic and social costs of transport systems. The institutional framework refers to norms and rules of governments as well as the collective actions, political commitments and social habits of people in a particular city. We have tried to emphasize the common elements, institutions and practices that frequently are part of the complex institutional framework of urban transport in Mexico.

Perhaps the main obstacle faced by urban transport projects is an outdated institutional framework. To some extent, this problem is caused by the relative disdain of the authorities towards proposals of transport operators or public transport users. However, any program or specific transport project must seek the active participation of both authorities and operators/users as an indispensable condition.

Federal authorities have jurisdiction throughout the national territory, state authorities within their states, and municipal authorities at the local level. Each has some specific role in urban transport management. Usually, there is a clear distribution of tasks, decisions and responsibilities for each level of government, but there could be exceptions.

Figure 22 is a diagram representing the major transportation decisions taken by three levels of government authorities in a Mexican city. This simplified schema describes the general characteristics of a complex decision-making process. In most major cities, the state government is directly responsible for the planning, design, operation and control of transportation systems, while federal authorities have had a relatively limited participation in projects of urban transport modernization. Municipal local governments are restricted to traffic control activities, public security and maintenance of the local road network. The design of new public policies to improve the performance of transport systems is not addressed by any specific level of government. 
The lack of a specific source of responsibility for change is a fundamental issue. As an OECD document has stated, "All levels of government -- national, regional and local - have important roles to play in assuring that effective policy options are identified and implemented." One might assume that municipalities could be more involved in modernization of their transportation systems, as local authorities have more information about transport problems. Unfortunately, except in most large cities, Mexican municipalities have a chronic lack of budgetary resources and an almost total lack of technical and specialized staff. State governments are in a better position to propose new transportation projects because their regulatory agencies have first-hand information. Especially in state capitals, where state governments are in charge on the granting concessions for the provision of public services, they regulate fare policy decisions, public service supervision, route design and some other activities. Federal government involvement has been primarily confined to budget support, although such support is often linked to implementation of federal policies. This linkage probably is caused by federal concern about the possibility of political interference in local or regional jurisdiction.

However, the situation seems to be changing in Mexico as the federal government is getting more involved. As stated in the OECD document cited above: "While most ECMT and OECD countries allocate the majority of responsibility for urban land-use and travel policies to regions and municipalities, there is growing recognition that National Government's role can be a determining factor in bringing about sustainability in urban areas." ${ }^{5}$ Chapter 5 of the current report shows how the federal government has been developing an integrated policy framework for urban mobility.

Three secretariats in the federal government have roles in the development and implementation of urban mobility policies.

- The Communications and Transport Secretariat (SCT) is responsible for planning, construction, operation and regulation of the transport infrastructure necessary for national integration, and SCT is in charge of regulation of intercity transport. Thus, it can have a strong impact on the performance of regional or local transport. Moreover, SCT is responsible for proper integration of intercity transport infrastructure with the urban transport infrastructure.

4. ECMT-OCDE Implementing sustainable urban transport policies. CEMT/CM (2001) 13, p. 4.

5. Ibid, p. 4. 


\section{Figure 22 Simplified diagram of decision making process for urban transport}

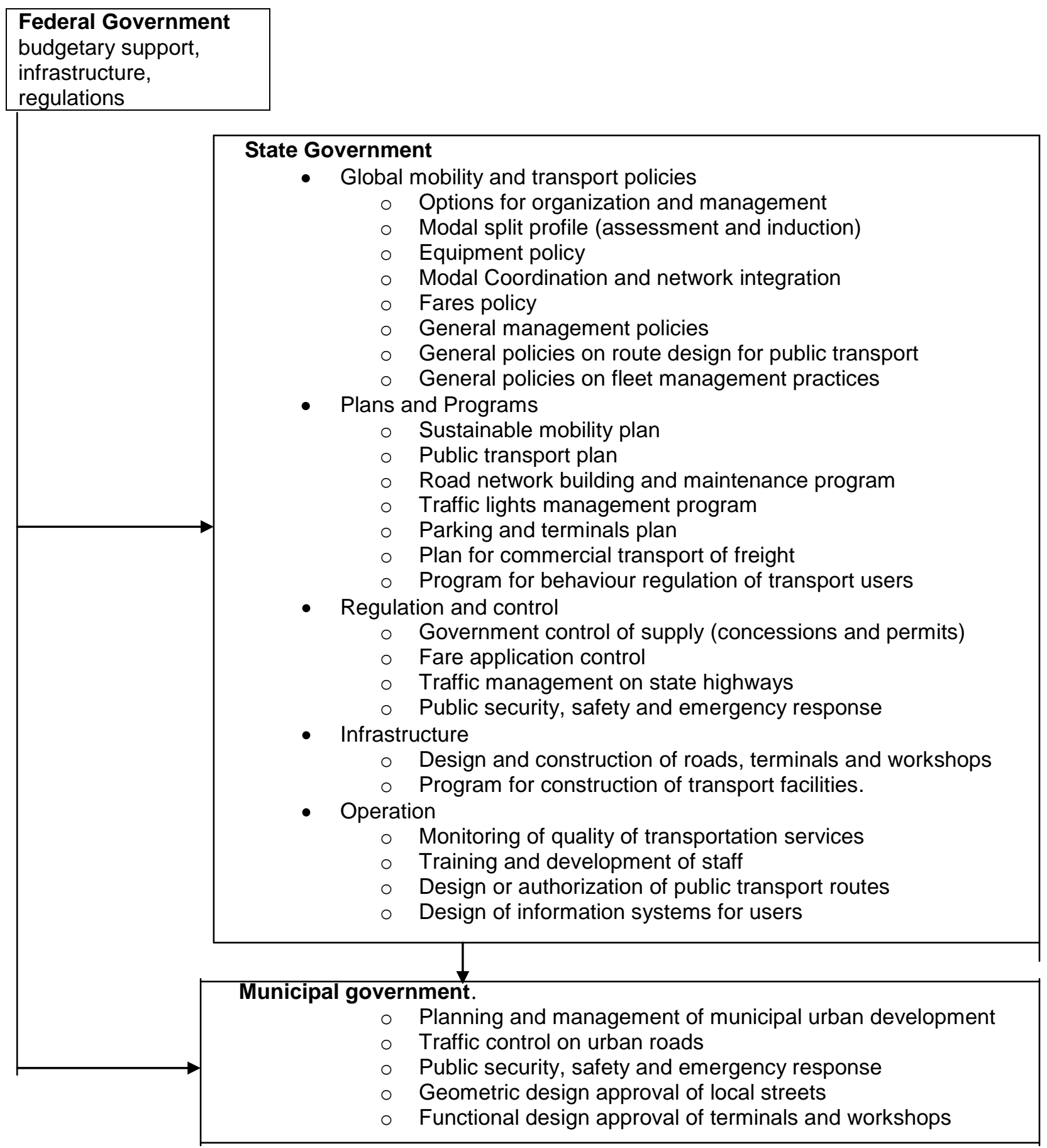


- The Social Development Secretariat has the task of formulating national policy on urban development and urban transport policies necessary for sustainable urban development.

- The Finance and Public Credit Secretariat evaluates and provides funds for transportation projects and programs through the national budget. In addition, it decides the key elements of energy price policy.

Several other government offices make decisions affecting urban transport. For instance, the Economy Secretariat can formulate policies related to production and marketing of vehicles, and the Environment and Natural Resources Secretariat formulates policies on environmental protection .

State government organization is frequently a replica of the federal organization with a notable exception. In many cases, state governments do not have a transport secretariat. In those cases, there is generally a public works infrastructure in charge of infrastructure construction and maintenance, and transport services are regulated by a government secretariat or a public security secretariat.

Although in some Mexican cities the municipal government is responsible for policies and projects related to urban transport, in most cities the state government formulates urban transport policy and implements projects.

Usually there are no conflicts over the primacy of an authority over the rightful jurisdiction over a project, policy or specific action related to urban transportation. Law, tradition and political reality work properly. Sometimes, however, different levels of government lack coordination on a particular project. A special complication occurs in the suburbs of growing cities when several municipalities are involved, or even several states as in MCMA. The coordination of efforts between different levels of government, various authorities and multiple transport operators can be a major obstacle to transport modernization. This is an issue that must be changed in order to transform the public transport in the cities of Mexico.

Both public and private capital support public passenger transportation. In some cities government is responsible not only for infrastructure and regulation but also for the service itself. Particularly in Mexico City, mass transportation systems such as the subway and light rail are operated by decentralized agencies under the Federal District Government. Lower-capacity systems of public transportation, like individual taxis, collective taxis (peseros), and tourism buses are operated by private organizations or individuals. An exception is the RTP (Red de Transporte de Pasajeros del D. F.) service of diesel passenger buses, a business that depends on the Federal District Government coexisting with several private operators, including firms created to operate Bus Rapid Transit (BRT) services.

Most organizations that supply urban passenger transport service are groups of individuals operating together but not necessarily as a traditional firm. It is very common to find in Mexican cities informal groups of individuals identified as "hombre-camión" ("man-and-a-truck"), who own a concession to operate one or several vehicles. Such informal groups have many organizational, technical and infrastructural deficiencies. They cannot exploit economies of scale or improve services. This issue could be, in most Mexican cities, the main challenge to overcome by transport authorities. It is almost impossible to convince transport operators about advantages of modernization if they believe that the real motivation is to displace them from the market. 
Bus Rapid Transit can transform current groups of transport operators into professional firms. The technology of the BRT-Metrobus project in Mexico City made it virtually impossible for peseros to operate under traditional patterns. A merit of BRT-Metrobus has been the inclusion of former peseros in the modernization project as a prerequisite for its viability.

\section{TOWARDS A NEW STRATEGY FOR SUSTAINABLE URBAN MOBILITY}

This chapter describes elements that illustrate the trends of urban transport policy. We review federal government programs focused on sustainable urban mobility and describe some of the sustainable transport projects and actions in Mexican cities.

\section{Current national strategy for sustainable transportation.}

The Federal Government's National Development Plan ("Plan Nacional de Desarrollo 2007-2012"), has two programs to improve the performance of urban transport in Mexico. In general terms, each seeks to increase the efficiency and quality of urban transportation services and limit the negative impacts on the environment. These two programs are the Federal Support for Mass Transit Program ("Programa Federal de Apoyo al Transporte Masivo", PROTAM) and the Urban Transport Transformation Program ("Programa para la Transformación del Transporte Urbano", PTTU).

\section{Federal Support for Mass Transit Program (PROTAM)}

The federal government's source of funding for transport projects is the National Bank for Public Works and Services ("Banco Nacional de Obras y Servicios"). Recently, the federal government created the National Infrastructure Fund (FONADIN) as a trust in the national bank to promote investments in infrastructure through grants, loans and guarantees. This infrastructure fund is an important instrument for coordinating the investment in the areas of communications, transport, environment, tourism, and others.

The FONADIN Technical Committee in 2008 approved the use of its funds to finance urban mass transit systems of PROTAM. Thus funded, PROTAM began looking for projects to modernize urban and suburban public transport, mainly for cities over 500000 inhabitants. Selected projects must be oriented to providing more efficient, safe, comfortable, reliable and accessible service to the majority of the population.

PROTRAM has two principle objectives:

a) To provide financial and technical support for mass transit infrastructure projects with high social returns, whenever they are congruent with the Comprehensive Plan for Sustainable Urban Mobility, which encourages participation of private investment and municipal financial resources.

b) To promote the institutional strengthening of local authorities on planning, regulation and management of integrated urban and suburban public transport. 
PROTRAM provides financial support for studies and preliminary proposals directly related to infrastructure projects in urban mass transport systems like Bus Rapid Transit, tramway, light rail transit, commuter trains and subways.

Among other specific actions, PROTRAMs seek to carry out the following:

- To coordinate the interaction of local, state and federal policies for sustainable development in transport, environment, urban development and social well-being.

- To improve planning, formulation, administration and implementation of projects, incorporating best practices in the field.

- To improve the assessment and selection process of projects, using proven methodologies that maximize the participation of the private sector and encourage the adoption of innovative and cost-efficient technologies.

- To promote the projects with highest social benefits, based on their technical, economic and environmental feasibility.

- To strengthen government capabilities in planning and management of public urban transport.

- To promote sustainable development.

\section{Urban Transport Transformation Project (PTTU)}

The Mexican Federal Government obtained access to a loan for PTTU from the Clean Technology Fund managed by the National Bank for Public Works and Services along with a loan from the International Bank for Reconstruction and Development. The PTTU objective is to encourage urban transport in cities and metropolitan areas of the country to reduce carbon emissions.

PTTU provides loans:

- To encourage development of efficient and sustainable urban transport systems.

- To reduce emissions of greenhouse gases and pollution.

- To improve the quality of urban passenger transport services.

- To provide incentives to achieve the transformation of urban transport.

- To promote the use of clean technologies in urban transport.

PTTU will be used to finance all or part of the "Eligible Projects" or "Selected Actions" that fulfil parameters of the three following components:

- Capacity Building (Component 1): funding for training and technical assistance to eligible beneficiaries in order to develop and strengthen institutional capacity to carry out the process of planning, regulation and management of urban transport.

- Development of Integrated Transport Systems that reduce CO2 emissions (Component 2 ): funding for mass transit corridors and ancillary investments, and low carbon bus technologies and the scrapping of displaced buses.

- Project Management (Component 3): provision of support to eligible projects for the supervision and monitoring of implementation of subprojects. 


\section{Environmental and Social Management Framework for Urban Transport (MASTU)}

This framework ("Marco de salvaguarda ambiental y social para el programa nacional de transformación del transporte urbano sustentable en Mexico", MASTU) is a document from the National Bank for Public Works and Services and it is part of the PROTRAM guidelines. The World Bank says that "MASTU establishes the social and environmental procedures and institutional responsibilities to ensure that subprojects will include adequate prevention, mitigation and compensation measures to address and minimize the potential environmental and social impacts of construction and/or operation of the different subprojects and to ensure socioenvironmental sustainability of sub-projects."

The methodology categorizes projects according to environmental or social problems that can be identified, seeking to ensure that they are subjected to relevant environmental and social assessments.

To this end, MASTU contains:

- Information about the program's legal and institutional framework.

- Procedures and responsibilities of the different stakeholders.

- General guidelines to prepare environmental impact assessments, environmental management plans and social programs adapted to conditions of each city.

MASTU fulfilment is mandatory for all projects in order to be approved by decision-makers of the National Infrastructure Fund and to receive financial support under PROTRAM. In the case of projects proposed under PTTU, MASTU fulfilment is a condition to be eligible for financial resources from the Clean Technology Fund, the National Bank for Public Works and Services and the International Bank for Reconstruction and Development.

\section{Some key sustainable transportation projects}

This section describes some of the most recent urban transport projects and government programs that could be considered good practices for sustainable transportation.

\section{The Integrated Transport System (SIT-Optibus)}

The Optibus is the mass transportation system of the city of Leon, Guanajuato. It was inaugurated on 2003. Leon was the first Mexican city to develop Bus Rapid Transit. The system divides bus routes into three categories, two of which use previous services. The new BRT service, operated by Optibús, uses articulated buses on five main routes. Feeder routes operated by regular urban buses were integrated into the system, and auxiliary routes allow transport users to reach a specific transfer station. At the conclusion of the third stage of the system it will service about $80 \%$ of urban transport users, or more than 500000 people.

\section{Mass transit in Guadalajara}

Guadalajara has two mass transit systems operated by a single company, the "Sistema de Tren Eléctrico Urbano" (Siteur). Siteur operates two lines of Guadalajara Metro (light rail transit) and a special feeder route called Pre-Train. Siteur also manages the Bus Rapid Transit service inaugurated in 2009 called "Macrobus." The main corridor on Independence Avenue has 27 stations, 41 articulated buses (each with capacity for 160 persons) and 15 feeder routes with

6. World Bank, 2009. Executive summary of the draft environmental and social assessment. Urban Transport Transformation Program. 
103 vehicles. The route covers 80 kilometres and services 130000 passengers daily. Ten additional Macrobus corridors have been proposed to improve the current inefficient public transport in this city of about 4.5 million people.

\section{Metrobus system in Mexico City}

With support from the Global Environment Facility and World Bank, the Federal District Government initiated the project "Introduction of Environmentally Friendly Measures with Transport in the Metropolitan Area of Mexico City," which includes a proposal for the Metrobus BRT on confined tracks. Metrobus is also a strategic element of the "Program to Improve Air Quality in the Metropolitan Area of Mexico 2002-2010," the "Local Strategy for Climate Action" and the "Integral Plan of Roads and Transport in Mexico City 2001-2006."

The Metrobus project includes a reform of conventional public transport. Important changes include a new organization to improve service and business operation, an improved infrastructure to achieve a faster flow of vehicles, and modernization of the vehicle fleet to achieve greater energy efficiency and fewer emissions.

The first Metrobus line was built on Insurgentes Avenue, a route of 19 kilometres. Nine additional BRT corridors are proposed for Mexico City, which implies a program of 200 kilometres of confined tracks and 800 articulated buses replacing 3000 microbuses and saving 214000 tonnes of $\mathrm{CO} 2$ emissions every year. ${ }^{7}$

\section{Bikeways program}

In order to promote non-polluting modes of transport, the Federal District Government developed a project of 75 kilometres of bikeways in Mexico City called "Ciclovía de la Ciudad de México." In this network, the speed of bikers on short trips is similar to that of cars in urban areas and faster than public transport and cars in congested areas. Virtually anyone can purchase a bicycle and its cost can be recovered by not taking public transport. Bicycling is allowed on the STC-Metro and Metrobus route system on Sundays, and the government are testing a bicycle rental operation that can be used in the bikeway system, Chapultepec Park and in the neighbourhood of Coyoacan.

\section{Taxi Replacement Program}

This program for taxi owners began in 2002. The Federal District Government grants a subsidy of MXN 15000 pesos that covers the first payment on a new vehicle, in exchange for the old vehicle which is then destroyed and recycled. The program includes training for taxi owners, provided by Nacional Financiera, covering topics related to the management of credit, personal finance, and improving service.

The objectives of program are:

- To reduce polluting emissions

- To increase road safety

- To contribute to the reduction of vehicle theft

- To ensure the withdrawal old vehicles from circulation.

The replacement of 3000 taxis will reduce greenhouse gas emissions by 14165 tonnes.

7. Secretaría del Medio Ambiente del Distrito Federal, 2008. "Programa de Acción Climática de la Ciudad de México 2008-2012". 


\section{CONCLUSIONS}

The process of urbanization and population growth in recent decades in Mexico involves quantitative and qualitative pressure on transport systems to adequately address the transportation needs of urban residents at the lowest economic and environmental cost possible.

Despite large investments and efforts of different levels of government in Mexico, road and transport networks in most cities are not prepared to meet growing travel demand, and road congestion is impressive in some cities. One limitation of transport networks is the excessive reliance on low-capacity vehicles. More comprehensive policies and programs must be developed, although we would obtain visible results only in the medium term.

Although most people still use public transport in Mexican cities, the use of private cars is growing. The result is traffic congestion, wasted time, lower productivity, and increasing demands for road space and parking facilities.

The main alternative to the automobile is mass transit. Such a change could be an efficient solution if and only if the transportation system in Mexican cities undergoes a process of professionalization resulting in a mass transit solution rather than a massive problem. Professional mass transportation companies would be the backbone of the entire system. With mass transit corridors we can exploit economies of scale and demonstrate to the rest of the public transportation system the advantages of automation and modern facilities.

Support for mass transit is not an issue of ideology or sympathy. We are not interested in a useless debate about mass transit versus automobile as the solution for urban transportation problems in Mexico. The support of mass transit is based on a number of technical reasons:

- It is the only option offering the required capacity in the main passenger corridors.

- It is more energy efficient per passenger. In fact, it is likely that only the increased use of electrified mass transportation can meet the challenge of diminishing fossil fuel availability.

- Urban planning and a more balanced urban-regional development are only feasible through the use of mass transit systems, with high levels of coverage, accessibility and quality of service.

- With mass transit, the infrastructure can handle a greater number of passengers per vehicle-kilometre.

- Mass transit use implies fewer hours spent travelling. That time could be devoted to productive activities, rest, enjoyment, or to the care of children, which is perhaps a very important social issue.

- It results in lower total cost per passenger-kilometre.

- It has higher levels of security and safety.

- A mass transit program could simplify the financing strategies for large transport companies that give professional and efficient service and provide a basis for reorganizing public transport, its financing and regulation. 
As for the problem of air pollution, actions to abate automobile emissions have been effective. However, other problems caused by growing numbers of automobiles remain. High levels of energy consumption, the sprawl of most Mexican cities and the really low quality of service in almost all public transport services, require a search for new public policies. The sustainability of cities is not solely an issue of environmental damage to the atmosphere.

Three main obstacles inhibit the creation of public policies that address growing demands for urban mobility in an efficient and environmentally sustainable way:

- The lack of economic resources to finance modernization of transportation systems.

- The accumulation of gaps in the organizational, technological, operational and infrastructural characteristics of most urban transport firms or groups of operators.

- An institutional framework that evolved to high levels of complexity. While it may have solved many past problems, now sometimes it fails when faced with new challenges because of new social needs, and it sometimes misses opportunities to incorporate new, more efficient technologies.

Although major changes seem to be happening in largest cities in Mexico, in many cities management of public transport is traditional, restricted to administration of concessions, mediation in fare disputes, or modernization of the road infrastructure. It is rare to find proposals for the implementation of public policies that actually involve, for example, an intermodal profile of lowest environmental and social costs.

Conscious of this problem, the Mexican federal government is implementing, with the assistance of some international organizations, a strategy focused on two core projects: the Federal Support for Mass Transit Program and the Urban Transport Transformation Program. Both programs are based on an explicit recognition of the obstacles mentioned above, and they include proper actions to address the main problems. However, some elements of the strategy to close the gap between policy recommendations and their implementation could be as follows:

- To promote the integration of all policies that may affect the central objectives of the strategy for sustainable urban transport. This recommendation remembers that "in order to bring about sustainable travel in urban areas, integrated policy packages -comprised of a cross-sectoral mix of regulatory, pricing, and technological measures among others -- are needed that send the right signals to both the supply and demand elements in urban land use and transport markets." ${ }^{8}$ In particular, two types of policies could be reviewed: those affecting the purchase of private vehicles, including financing, importation and the onboard technologies, and those affecting the relative price of fuel. The impact of these variables, along with the modernization and professionalization of public transport, are essential conditions to try to reverse current trends in motorization and energy consumption.

- To select only the mass transit projects that are fully justified. Funding should be conditional, subject to a rigorous process of assessment of technical and economic feasibility and compliance with environmental regulations. Nothing can have a worse impact on the strategy to promote sustainable, efficient mass transportation than a project which fails to offer the expected benefits.

8. ECMT-OCDE (2001). Implementing sustainable urban transport policies. CEMT/CM. p. 3. 
- To coordinate and integrate all modes of transport. Actions must go beyond rhetoric and political speech and should include electrical and non-motorized modes of transport. Modernization projects would be approved only if they include, in appropriate scale and in accordance with expected demand, all possible technologies including traditional modes and all types of users. Projects tailored to the human scale could be favoured. Currently, few urban transport projects include some aspect to provide greater accessibility to all users or to promote intermodal integration.

- To design and disseminate a "culture of acceptance" toward mass transit. Promoting a more favourable attitude to public transport is part of a strategy to reverse the preference of people to use a private car. The strong resistance of motorists to drive less often is well known, even when they have attractive options in public transport. It could be difficult to compete with commercial promotion of car sales, but it is worse to do nothing.

- To improve the instruments of urban transport management. Better concession procedures, fares approval, investment regulations, operating regulations, organizational structures, modernization projects, etc. might be necessary to properly implement new urban transport policies. Improvements at each level of government ensure efficient and safe mass transit operation. It is also necessary to improve the training of staff in all the areas of urban transport. Changing some parts of the institutional framework may be unavoidable in order to face the problems of obsolescent or inefficient practices that hinder decision making. In particular, it is important to achieve a wide and open-minded collaboration to have consistency between objectives and implementation of new policies.

- To promote research and development in the field of urban transport. R\&D is not only important for the creation or adaptation of technologies for vehicles and facilities. It is also necessary to design management tools of mass transportation systems. Modernization of mass transit requires the development of analytical tools that improve decision-making in planning, design, construction, operation and maintenance. Only $R \& D$ can provide an efficient use of resources in the management of transport systems, ensuring quality of service, safety, security, comfort, coverage, reliability and environmental friendliness. 


\section{BIBLIOGRAPHY}

Acquatella, Jean. (2001) Aplicación de los Instrumentos económicos en la gestión ambiental en América Latina y el Caribe: desafíos y factores condicionantes, Serie Medio ambiente y desarrollo, CEPAL.

Crass, M., and Miyake, M. (2005) Implementing Sustainable Urban Travel Polices: How can National Governments Help? Workshop on Implementing Sustainable Urban Travel Polices in Japan and other Asia -Pacific countries, ECMT, Tokyo.

Comisión de Vialidad y Transporte Urbano (1984) Estudio de origen y destino del área metropolitana de la ciudad de México, 1983. Departamento del Distrito Federal. México.

Delucchi , M.A. (2002) Environmental Externalities of Motor-Vehicle Use in the US. Journal of Transport Economics and Policy, Vol. 34, May.

ECMT/CM. (2000) Sustainable Development. Sustainable Transport Polices. European Conference of Ministers of Transport. Council of Ministers. Praga.

ECMT/CM. (2001) Implementing sustainable transport polices. European Conference of Ministers of Transport. Council of Ministers.

ECMT/CM. (2001) National Peer Review: The Netherlands. Implementing sustainable transport polices. European Conference of Ministers of Transport. Council of Ministers. OECD.

ECMT/CM. (2002) Implementing sustainable transport polices. Final Report. European Conference of Ministers of Transport. Council of Ministers.

ECMT/CM. (2002) Key Messages for Governments European Conference of Ministers of Transport. Council of Ministers.

ECMT/CM. (2003) Managing the Fundamental Driver of Transport Demand. Conclusions of the December 2002 Seminar. European Conference of Ministers of Transport. Council of Ministers. Brussels.

ECMT/CM (2003) National Reviews. Implementing sustainable transport polices. European Conference of Ministers of Transport. Council of Ministers. OECD.

ECMT/CM. (2003) Transport Policy: successes, failures and Challenges. European Conference of Ministers of Transport. Council of Ministers. Brussels.

ECMT/CM. (2006) Access and inclusion. Improving Transport Accessibility for all: Policy Messages. European Conference of Ministers of Transport. Council of Ministers. OECD.

ECMT/CM. (2006) Sustainable Urban Travel. Implementing Sustainable Urban Travel polices: Applying the 2001 Key Messages. European Conference of Ministers of Transport. Council of Ministers.

Fujii, S. (2005) Prospect for Mobility Management in Japan, Workshop on Implementing Sustainable Urban Travel Polices in Japan and other Asia-Pacific countries, ECMT, Tokyo. 
Implementing Sustainable Urban Travel Policies in Mexico

Gallopín, G. (2003) A systems approach to sustainability and sustainable development, Medio ambiente y desarrollo, CEPAL.

Gwilliam, K. (1997) Sustainable Transport and Economic Development. Journal of Transport Economics and Policy. University of Bath.

Hee K.J., (2005) Public Transport promotion polices to improve Urban Traffic Conditions. Workshop on Implementing Sustainable Urban Travel Polices in Japan and other AsiaPacific countries, ECMT, Tokyo.

INEGI (1994) Encuesta de Origen y Destino de los Viajes en el Área Metropolitana de la Ciudad de México. INEGI, Aguascalientes, México.

INEGI (2007) Encuesta 2007, Origen Destino. INEGI, Aguascalientes, México.

INEGI (2011) Censo General de Población y Vivienda, 2010. Resultados definitivos. Aguascalientes, México.

Instituto Mexicano del Transporte (2007) Estudio de la demanda en las principales terminales de pasajeros del Autotransporte Federal en la República Mexicana. IMT, SCT, Querétaro, México.

International Transport Forum (2009) The Future of interurban Passenger Transport-Bringing Citizens Closer Together. Symposium summary and Conclusions. Joint Transport Research Centre, Discussion paper 2010-11, OECD, Madrid.

International Transport Forum. (2010) Transport Outlook 2010. The Potential for Innovation, OECD/ITF. Paris.

Islas R., Víctor. (2000) Llegando tarde al compromiso: la crisis del transporte urbano en la ciudad de México. El Colegio de México, México.

May, A.D., (2005) Overcoming Institutional Barriers to the Implementation of Integrated Transport Strategies. Workshop on Implementing Sustainable Urban Travel Polices in Japan and other Asia-Pacific countries. ECMT, Tokyo.

Pearce, D.W. and Nash, C.A. (1981) The Social Appraisal of Projects: A Text in Cost-Benefit Analysis. Macmillan Ed. Ltd.

Sheinbaum Pardo, C. (2008) Problemática ambiental de la ciudad de México. Ed. Limusa, México.

Wenhua, W. (2005) Urban Travel in China: Continuing Challenges with Rapid Urbanization and Motorization. Workshop on Implementing Sustainable Urban Travel Polices in Japan and other Asia-Pacific countries, ECMT, Tokyo.

Weiner, E. (2003) Overview of the ECMT/OECD Project on Sustainable Urban Travel and Sustainable Development. ECMT-USDOT Workshop on Fostering Successful implementation of sustainable urban travel polices, Washington, D.C. 


\section{ANNEX (TABLES AND FIGURES)}

Table 1. Proportion of urban population and per capita GDP

\begin{tabular}{|c|c|c|c|c|c|c|}
\hline \multicolumn{4}{|c|}{ Population in 2010} & \multicolumn{3}{|c|}{ per capita GDP } \\
\hline State & Urban & Rural & Total & $\begin{array}{l}\text { Urbanization } \\
\text { index }\end{array}$ & Total & Manuf. \\
\hline Aguascalientes & 957683 & 227241 & 1184924 & $81 \%$ & 77.5 & 23.5 \\
\hline Baja California & 2910152 & 244022 & 3154174 & $92 \%$ & 73.8 & 15.3 \\
\hline Baja California Sur & 546502 & 90563 & 637065 & $86 \%$ & 83.7 & 2.4 \\
\hline Campeche & 613409 & 208592 & 822001 & $75 \%$ & 342.9 & 2.6 \\
\hline Chiapas & 2336080 & 2457326 & 4793406 & $49 \%$ & 31.0 & 2.4 \\
\hline Chihuahua & 2884392 & 516748 & 3401140 & $85 \%$ & 76.3 & 18.0 \\
\hline Coahuila & 2475809 & 272557 & 2748366 & $90 \%$ & 88.1 & 27.0 \\
\hline Colima & 570646 & 79483 & 650129 & $88 \%$ & 66.7 & 6.6 \\
\hline Distrito Federal & 8832267 & 40750 & 8873017 & $100 \%$ & 162.8 & 17.1 \\
\hline Durango & 1124097 & 508763 & 1632860 & $69 \%$ & 61.8 & 12.7 \\
\hline Guanajuato & 3831344 & 1654627 & 5485971 & $70 \%$ & 57.7 & 16.8 \\
\hline Guerrero & 1973051 & 1413655 & 3386706 & $58 \%$ & 36.7 & 2.3 \\
\hline Hidalgo & 1440178 & 1224791 & 2664969 & $54 \%$ & 44.1 & 12.7 \\
\hline Jalisco & 6360989 & 989366 & 7350355 & $87 \%$ & 72.0 & 16.3 \\
\hline México & 13190126 & 1984146 & 15174272 & $87 \%$ & 49.6 & 12.9 \\
\hline Michoacán & 2982808 & 1365677 & 4348485 & $69 \%$ & 45.7 & 5.5 \\
\hline Morelos & 1489924 & 286803 & 1776727 & $84 \%$ & 54.5 & 13.4 \\
\hline Nayarit & 747651 & 337306 & 1084957 & $69 \%$ & 47.6 & 2.6 \\
\hline Nuevo León & 4396055 & 247266 & 4643321 & $95 \%$ & 130.7 & 30.6 \\
\hline Oaxaca & 1810941 & 1990930 & 3801871 & $48 \%$ & 32.9 & 4.7 \\
\hline Puebla & 4153332 & 1625675 & 5779007 & $72 \%$ & 47.5 & 12.6 \\
\hline Querétaro & 1284340 & 543645 & 1827985 & $70 \%$ & 80.9 & 19.2 \\
\hline Quintana Roo & 1166089 & 158168 & 1324257 & $88 \%$ & 90.5 & 2.1 \\
\hline San Luis Potosí & 1652974 & 932968 & 2585942 & $64 \%$ & 57.1 & 13.4 \\
\hline Sinaloa & 2014681 & 752871 & 2767552 & $73 \%$ & 60.5 & 5.0 \\
\hline Sonora & 2294941 & 367491 & 2662432 & $86 \%$ & 75.3 & 14.3 \\
\hline Tabasco & 1284841 & 953977 & 2238818 & $57 \%$ & 100.0 & 4.1 \\
\hline Tamaulipas & 2869253 & 401015 & 3270268 & $88 \%$ & 81.4 & 10.3 \\
\hline Tlaxcala & 934158 & 235667 & 1169825 & $80 \%$ & 37.3 & 9.8 \\
\hline Veracruz & 4668059 & 2970319 & 7638378 & $61 \%$ & 50.0 & 7.4 \\
\hline Yucatán & 1640245 & 312782 & 1953027 & $84 \%$ & 60.2 & 8.4 \\
\hline Zacatecas & 884133 & 606417 & 1490550 & $59 \%$ & 45.3 & 6.2 \\
\hline National & 86321150 & 26001607 & $\begin{array}{r}112322 \\
757\end{array}$ & $77 \%$ & 71.0 & 12.4 \\
\hline
\end{tabular}

* Note: per capita GDP in 2009 (thousands of pesos), at constant prices of 2003.

Source: Censo General de Población y Vivienda 2010. Resultados definitivos, INEGI. 
Implementing Sustainable Urban Travel Policies in Mexico

Table 2. Growth of vehicles in Mexico.

\begin{tabular}{|c|c|c|c|}
\hline & \multicolumn{3}{|c|}{ Registered Vehicles } \\
\hline & 2000 & 2005 & 2010* \\
\hline Mexico (country) & 15611916 & 22155421 & 33408332 \\
\hline Aguascalientes & 198046 & 316559 & 455792 \\
\hline Baja California & 752607 & 1187451 & 1655310 \\
\hline Baja California Sur & 185233 & 321122 & 499311 \\
\hline Campeche & 73644 & 97928 & 225781 \\
\hline Chiapas & 222570 & 304827 & 598593 \\
\hline Chihuahua & 811990 & 1001292 & 1303137 \\
\hline Coahuila & 334131 & 622732 & 807204 \\
\hline Colima & 73137 & 160842 & 238343 \\
\hline Federal District & 2511543 & 2713163 & 4284773 \\
\hline Durango & 164791 & 309947 & 437497 \\
\hline Guanajuato & 599774 & 914635 & 1380427 \\
\hline Guerrero & 346367 & 717576 & 695860 \\
\hline Hidalgo & 363565 & 613043 & 925408 \\
\hline Jalisco & 1303109 & 2066373 & 2971379 \\
\hline State of Mexico & 1268894 & 1473208 & 3005505 \\
\hline Michoacan & 686611 & 1012983 & 1641998 \\
\hline Morelos & 221609 & 289315 & 405359 \\
\hline Nayarit & 118177 & 234897 & 340195 \\
\hline Nuevo Leon & 952866 & 1451581 & 2080349 \\
\hline Oaxaca & 184556 & 284563 & 354401 \\
\hline Puebla & 523127 & 751523 & 1222103 \\
\hline Queretaro & 231004 & 271896 & 453816 \\
\hline Quintana Roo & 142093 & 224246 & 460102 \\
\hline San Luis Potosi & 330168 & 547556 & 854867 \\
\hline Sinaloa & 386732 & 573867 & 939281 \\
\hline Sonora & 514396 & 599007 & 981237 \\
\hline Tabasco & 187642 & 250576 & 411066 \\
\hline Tamaulipas & 734129 & 971514 & 1024509 \\
\hline Tlaxcala & 96942 & 130649 & 221236 \\
\hline Veracruz & 611618 & 1004913 & 1511003 \\
\hline Yucatan & 214190 & 344530 & 484478 \\
\hline Zacatecas & 266655 & 391107 & 538010 \\
\hline
\end{tabular}

Source: INEGI, 2010. Estadística de vehículos de motor registrados en circulación. México. 
Table 3. Motorization rate: vehicles per capita

\begin{tabular}{lrrr}
\hline & \multicolumn{3}{c}{ Motorization rate } \\
& \multicolumn{3}{c}{ (vehicles/thousand people) } \\
& $\mathbf{2 0 0 0}$ & $\mathbf{2 0 0 5}$ & $\mathbf{2 0 1 0}$ \\
\hline Mexico (country) & 160.1 & 214.6 & 297.4 \\
\hline Aguascalientes & 209.7 & 297.1 & 384.6 \\
\hline Baja California & 302.6 & 417.5 & 524.7 \\
\hline Baja California Sur & 436.8 & 627.0 & 783.8 \\
\hline Campeche & 106.6 & 129.8 & 274.5 \\
\hline Chiapas & 56.8 & 71.0 & 124.8 \\
\hline Chihuahua & 266.0 & 308.9 & 382.5 \\
\hline Coahuila & 145.4 & 249.6 & 293.7 \\
Colima & 134.8 & 283.2 & 366.4 \\
\hline Federal District & 291.9 & 311.1 & 484.1 \\
\hline Durango & 113.8 & 205.4 & 267.9 \\
\hline Guanajuato & 128.6 & 186.9 & 251.6 \\
Guerrero & 112.5 & 230.3 & 205.3 \\
\hline Hidalgo & 162.6 & 261.4 & 347.2 \\
\hline Jalisco & 206.1 & 306.0 & 404.2 \\
\hline State of Mexico & 96.9 & 105.2 & 198.0 \\
\hline Michoacan & 172.3 & 255.4 & 377.4 \\
\hline Morelos & 142.5 & 179.4 & 228.1 \\
\hline Nayarit & 128.4 & 247.3 & 313.6 \\
\hline Nuevo Leon & 129.2 & 189.4 & 247.7 \\
\hline Oaxaca & 197.0 & 286.0 & 360.9 \\
\hline Puebla & & & \\
\hline Queretaro & 248.5 & 345.7 & 447.1 \\
\hline Quintana Roo & 53.7 & 81.1 & 93.2 \\
\hline San Luis Potosi & 103.0 & 139.6 & 211.4 \\
\hline Sinaloa & 164.5 & 170.1 & 248.3 \\
\hline Sonora & 162.4 & 197.5 & 347.1 \\
\hline Tabasco & 143.6 & 227.2 & 330.6 \\
\hline Tamaulipas & 152.4 & 220.0 & 339.4 \\
\hline Tlaxcala & 232.0 & 250.1 & 368.5 \\
\hline Veracruz & 99.2 & 125.9 & 183.6 \\
\hline Yucatan & 266.6 & 321.2 & 313.4 \\
Zacatecas & 100.7 & 122.3 & 189.1 \\
\hline & 88.5 & 141.3 & 197.7 \\
\hline
\end{tabular}

Source: Elaboración propia con base en la información de los cuadros A.1 y A.2. 
Table 4. Main air pollutants in the MCMA

\begin{tabular}{l}
\hline $\mathrm{PST}=$ Total Suspended Particles. \\
$\mathrm{PM} 10=$ Particles smaller than $10 \mu \mathrm{m}$. \\
$\mathrm{PM} 2.5=$ Particles smaller than $2.5 \mu \mathrm{m}$. \\
$\mathrm{SO}_{2}=$ Sulfur Dioxide. \\
$\mathrm{CO}=$ Carbon Monoxide. \\
$\mathrm{NO}_{\mathrm{x}}=$ Nitrogen Oxides. \\
$\mathrm{Pb}=$ Lead. \\
$\mathrm{O}_{3}=$ Ozone. \\
$\mathrm{COT}=$ Total Organic Pollutants. \\
$\mathrm{NH}_{3}=$ Ammonia. \\
$\mathrm{CH}_{4}=$ Methane. \\
$\mathrm{COV}=$ Volatile Organic Compounds. \\
\hline
\end{tabular}

Table 5. Percentage of emissions in MCMA, disaggregated by source, 2004

\begin{tabular}{|c|c|c|c|c|c|c|c|c|c|}
\hline & $\mathrm{PM}_{10}$ & $\mathrm{PM}_{2.5}$ & $\mathrm{SO}_{2}$ & $\mathrm{CO}$ & NOx & СOT & $\mathrm{CH}_{4}$ & cov & $\mathrm{NH}_{3}$ \\
\hline Local sources & 18.93 & 9.83 & 49.41 & 0.36 & 10.97 & 14.56 & 0.66 & 21.44 & 1.12 \\
\hline Area sources & 52.21 & 29.63 & 0.62 & 0.43 & 6.48 & 59.20 & 95.16 & 40.68 & 77.33 \\
\hline Mobile sources & 23.05 & 56.60 & 49.97 & 99.21 & 82.21 & 24.09 & 4.18 & 34.56 & 21.55 \\
\hline $\begin{array}{l}\text { Land and } \\
\text { vegetation }\end{array}$ & 5.81 & 3.94 & $\mathrm{~N} / \mathrm{A}$ & $\mathrm{N} / \mathrm{A}$ & 0.35 & 2.14 & $\mathrm{~N} / \mathrm{A}$ & 3.31 & $\mathrm{~N} / \mathrm{A}$ \\
\hline TOTAL & 100.00 & 100.00 & 100.00 & 100.00 & 100.00 & 100.00 & 100.00 & 100.00 & 100.00 \\
\hline
\end{tabular}

Source: Own calculations based on data from Sheinbaum, C., 2008. "Problemática ambiental de la ciudad de México", Limusa, México.

Table 6. Emissions Inventory in the MCMA, disaggregated by mobile source, 2004 (tonnes per year).

\begin{tabular}{|c|c|c|c|c|c|c|c|c|c|}
\hline & $\mathrm{PM}_{10}$ & $\mathrm{PM}_{2.5}$ & $\mathrm{SO}_{2}$ & CO & NOx & СOT & $\mathrm{CH}_{4}$ & cov & $\mathrm{NH}_{3}$ \\
\hline Cars & 860 & 480 & 1719 & 890602 & 57456 & 92689 & 3931 & 85849 & 2648 \\
\hline Taxis & 144 & 80 & 312 & 118709 & 11062 & 14309 & 606 & 13252 & 483 \\
\hline Combis & 24 & 14 & 44 & 69194 & 3208 & 6687 & 283 & 6193 & 76 \\
\hline Microbuses & 42 & 24 & 123 & 151556 & 10278 & 18767 & 1461 & 17456 & 171 \\
\hline Pick up & 63 & 36 & 149 & 106338 & 8572 & 10825 & 515 & 10012 & 169 \\
\hline Up to 3 tonnes vehicles & 283 & 234 & 215 & 109111 & 10695 & 11908 & 478 & 11084 & 117 \\
\hline Heavy trucks & 2315 & 2014 & 284 & 31945 & 29094 & 11575 & 494 & 11069 & 30 \\
\hline Buses & 691 & 600 & 261 & 16015 & 10751 & 4741 & 204 & 4530 & 14 \\
\hline $\begin{array}{l}\text { More than } 3 \text { tonnes } \\
\text { vehicles }\end{array}$ & 270 & 223 & 152 & 186038 & 5798 & 12989 & 1030 & 11715 & 45 \\
\hline Motorcycles & 76 & 43 & 62 & 98399 & 1057 & 16646 & 814 & 12739 & 22 \\
\hline Total & 4768 & 3748 & 3321 & 1777907 & 147971 & 198136 & 9816 & 183899 & 3775 \\
\hline
\end{tabular}

Source: idem to table 5. 
Implementing Sustainable Urban Travel Policies in Mexico

Table 7. Kilometers traveled by type of vehicle in the MCMA, 1994-2006.

\begin{tabular}{|c|c|c|c|c|c|c|c|c|}
\hline & \multicolumn{7}{|c|}{ Millions of vehicle-kilometer } & \multirow[b]{2}{*}{ AGR } \\
\hline & 1994 & 1996 & 1998 & 2000 & 2002 & 2004 & 2006 & \\
\hline Cars & 27666 & 27813 & 34069 & 38910 & 41341 & 44694 & 48538 & 4.8 \\
\hline Taxis & 4336 & 5773 & 6050 & 6873 & 7039 & 7636 & 10376 & 7.5 \\
\hline Combis & 1312 & 1312 & 1303 & 1241 & 1233 & 1252 & 2030 & 3.7 \\
\hline Microbuses & 2025 & 2025 & 1978 & 2000 & 1925 & 2098 & 2276 & 1.0 \\
\hline Pick up & 3674 & 3525 & 3733 & 3714 & 3687 & 3246 & 2769 & -2.3 \\
\hline $\begin{array}{l}\text { Up to } 3 \text { tonnes } \\
\text { vehicles }\end{array}$ & 853 & 869 & 890 & 945 & 1090 & 1084 & 1098 & 2.1 \\
\hline Heavy trucks & 1088 & 1168 & 1116 & 1375 & 1652 & 1815 & 1910 & 4.8 \\
\hline Buses & 517 & 496 & 523 & 578 & 807 & 944 & 1633 & 10.1 \\
\hline $\begin{array}{l}\text { More than } 3 \\
\text { tonnes vehicles }\end{array}$ & 990 & 975 & 969 & 995 & 1075 & 1130 & 1228 & 1.8 \\
\hline Motorcycles & 931 & 1345 & 1827 & 2391 & 2534 & 3152 & 4538 & 14.1 \\
\hline TOTAL & 43422 & 45301 & 54456 & 61022 & 62383 & 67051 & 76396 & 4.8 \\
\hline
\end{tabular}

Source: Idem to table 5.

Table 8 Emissions per vehicle-kilometer in 2004

\begin{tabular}{|c|c|c|c|c|c|c|}
\hline & \multicolumn{6}{|c|}{ Grams of pollutant per vehicle-kilometer } \\
\hline & $\mathrm{PM}_{10}$ & $\mathrm{PM}_{2.5}$ & $\mathrm{SO}_{2}$ & CO & NOx & COT \\
\hline Cars & 0.019 & 0.011 & 0.038 & 19.927 & 1.286 & 2.074 \\
\hline Taxis & 0.019 & 0.010 & 0.041 & 15.546 & 1.449 & 1.874 \\
\hline Combis & 0.019 & 0.011 & 0.035 & 55.267 & 2.562 & 5.341 \\
\hline Microbuses & 0.020 & 0.011 & 0.059 & 72.238 & 4.899 & 8.945 \\
\hline Pick up & 0.019 & 0.011 & 0.046 & 32.760 & 2.641 & 3.335 \\
\hline $\begin{array}{l}\text { Up to } 3 \text { tonnes } \\
\text { vehicles }\end{array}$ & 0.261 & 0.216 & 0.198 & 100.656 & 9.866 & 10.985 \\
\hline Heavy trucks & 1.275 & 1.110 & 0.156 & 17.601 & 16.030 & 6.377 \\
\hline Buses & 0.732 & 0.636 & 0.276 & 16.965 & 11.389 & 5.022 \\
\hline $\begin{array}{l}\text { More than } 3 \text { tonnes } \\
\text { vehicles }\end{array}$ & 0.239 & 0.197 & 0.135 & 164.635 & 5.131 & 11.495 \\
\hline Motorcycles & 0.024 & 0.014 & 0.020 & 31.218 & 0.335 & 5.281 \\
\hline TOTAL & 0.071 & 0.056 & 0.050 & 26.516 & 2.207 & 2.955 \\
\hline
\end{tabular}

Source: Own calculations based on data from tables 6 and 7. 
Implementing Sustainable Urban Travel Policies in Mexico

Table 9. Trends in hourly concentrations (annual average) of main air pollutants in MCMA.

\begin{tabular}{|c|c|c|c|c|c|c|c|c|c|c|c|}
\hline & 1988 & 1989 & 1990 & 1991 & 1992 & 1993 & 1994 & 1995 & 1996 & 1997 & 1998 \\
\hline PST $\left(\mu \mathrm{g} / \mathrm{m}^{3}\right)$ & NM & 248 & 337 & 482 & 354 & 190 & 179 & 166 & 208 & 209 & 210 \\
\hline$P M_{10}\left(\mu g / m^{3}\right)$ & NM & 177 & 117 & 100 & 82 & 106 & 99 & 89 & 88 & 76 & 86 \\
\hline $\mathrm{PM}_{2.5}\left(\mu \mathrm{g} / \mathrm{m}^{3}\right)$ & NM & NM & NM & NM & NM & NM & NM & NM & NM & NM & NM \\
\hline $\mathrm{SO}_{2}(\mathrm{ppm})$ & 0.057 & 0.051 & 0.058 & 0.059 & 0.046 & 0.023 & 0.02 & 0.017 & 0.016 & 0.014 & 0.013 \\
\hline CO (ppm) & 6.2 & 6.6 & 7.1 & 8.7 & 8 & 5.3 & 4.8 & 3.8 & 4 & 3.6 & 3.5 \\
\hline NOx (ppm) & 0.117 & 0.109 & 0.19 & 0.131 & DI & 0.235 & 0.176 & 0.171 & 0.2 & 0.196 & 0.153 \\
\hline $\mathrm{Pb}\left(\mu \mathrm{g} / \mathrm{m}^{3}\right)$ & 1.29 & 1.4 & 1.23 & 0.88 & 0.54 & 0.29 & 0.25 & 0.19 & 0.25 & 0.16 & 0.1 \\
\hline \multirow[t]{2}{*}{$\mathrm{O}_{3}(\mathrm{ppm})$} & 0.13 & 0.119 & 0.141 & 0.174 & 0.155 & 0.134 & 0.138 & 0.135 & 0.123 & 0.117 & 0.115 \\
\hline & 1999 & 2000 & 2001 & 2002 & 2003 & 2004 & 2005 & 2006 & 2007 & 2008 & 2009 \\
\hline PST $\left(\mu \mathrm{g} / \mathrm{m}^{3}\right)$ & 238 & 202 & 177 & 173 & 173 & 148 & 165 & 122 & 113 & 132 & 143 \\
\hline $\mathrm{PM}_{10}\left(\mu \mathrm{g} / \mathrm{m}^{3}\right)$ & 78 & 71 & 60 & 62 & 66 & 56 & 56 & 50 & 46 & 53 & 60 \\
\hline $\mathrm{PM}_{2.5}\left(\mu \mathrm{g} / \mathrm{m}^{3}\right)$ & NM & NM & NM & NM & DI & 24 & 25 & 22 & 21 & 22 & 21 \\
\hline $\mathrm{SO}_{2}(\mathrm{ppm})$ & 0.013 & 0.018 & 0.016 & 0.012 & 0.012 & 0.012 & 0.011 & 0.007 & 0.007 & 0.006 & 0.006 \\
\hline CO (ppm) & 3.1 & 3.3 & 3 & 2.6 & 2.4 & 2.2 & 2 & 1.9 & 1.7 & 1.6 & 1.4 \\
\hline NOx (ppm) & 0.145 & 0.146 & 0.134 & 0.142 & 0.161 & 0.16 & 0.159 & 0.154 & 0.153 & 0.157 & 0.14 \\
\hline $\left.\mathrm{Pb} \mu \mathrm{g} / \mathrm{m}^{3}\right)$ & 0.16 & 0.09 & 0.08 & 0.08 & 0.09 & 0.07 & 0.05 & 0.06 & 0.07 & 0.03 & 0.04 \\
\hline $\mathrm{O}_{3}(\mathrm{ppm})$ & 0.108 & 0.116 & 0.104 & 0.102 & 0.097 & 0.088 & 0.09 & 0.085 & 0.084 & 0.082 & 0.082 \\
\hline
\end{tabular}

Source: Own calculations based on data from "Informe 2009 de la calidad del aire en la ciudad de México". Secretaría del Medio Ambiente. Gobierno del Distrito Federal, 2010.

Table 10. Environmental norms for the United States and Mexico.

\begin{tabular}{|c|c|c|c|c|c|c|c|}
\hline & $\begin{array}{c}\text { CO } \\
(p p m)\end{array}$ & $\begin{array}{c}\mathrm{SO} 2 \\
\text { (ppm) }\end{array}$ & $\begin{array}{c}\text { O3 } \\
\text { (ppm) }\end{array}$ & $\begin{array}{c}\text { NO2 } \\
\text { (ppm) }\end{array}$ & $\begin{array}{c}\text { PM10 } \\
(\mu \mathrm{g} / \mathrm{m} 3)\end{array}$ & $\begin{array}{c}\text { PM2.5 } \\
(\mu \mathrm{g} / \mathrm{m} 3)\end{array}$ & $\begin{array}{c}\text { Lead } \\
(\mu \mathrm{g} / \mathrm{m} 3)\end{array}$ \\
\hline United States & $\begin{array}{l}35(1 \mathrm{~h}) \\
9(8 \mathrm{~h})\end{array}$ & $0.13(24 h)$ & $\begin{array}{l}0.08(1 \mathrm{~h}) \\
0.06(8 \mathrm{~h})\end{array}$ & $0.21(1 \mathrm{~h})$ & $150(24 h)$ & 65 (24h) & 1.5 (average) \\
\hline Mexico & 11 (8h) & $0.13(24 h)$ & $\begin{array}{l}0.11(1 \mathrm{~h}) \\
0.08(8 \mathrm{~h})\end{array}$ & $0.21(1 \mathrm{~h})$ & $120 \mathrm{a}(24 \mathrm{~h})$ & $65 a(24 h)$ & $\begin{array}{l}1.5 \text { (average in } \\
\text { three months) }\end{array}$ \\
\hline
\end{tabular}

Source: Idem to table 5. 
E International

International Transport Forum

2 rue André Pascal

75775 Paris Cedex 16

itf.contact@oecd.org

www.internationaltransportforum.org 